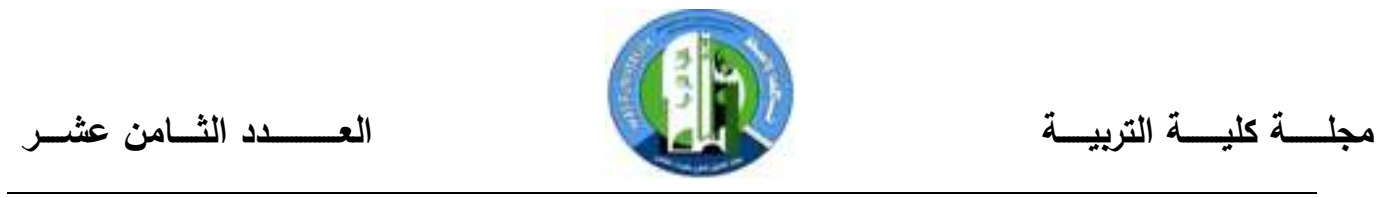

\title{
الأمطار القياسية اليومية في العلق (دراسة شمولية)
}

\section{د. مالك ناصر عبود الكناني \\ جامعة وإسط/ كلية التربية}

المستخلص: إن سقوط أعلى الأمطار اليومية في العراق ناتج عن نكرار ثلاثة منخفضات جوية وهي: المنخفض الجوي المتوسطي والمنخفض الجوي المندمج والمنخفض الجوي السوداني، وتبين أنّ التِ كميات أعلى مطرة في العراق تتباين بين منطقة وأخرى بسبب طبيعة المنخفضات الجوية المؤثرة فيها ومسالكها والظروف الجوية السائدة معها والأنماط الضغطية المرافقة لها في طبقات الجو العليا.

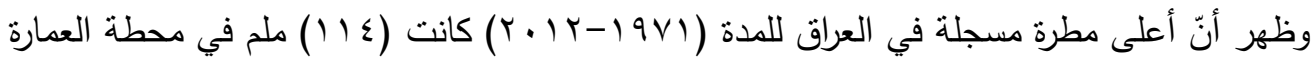

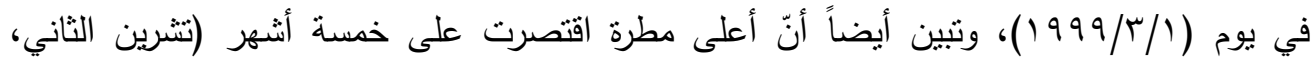

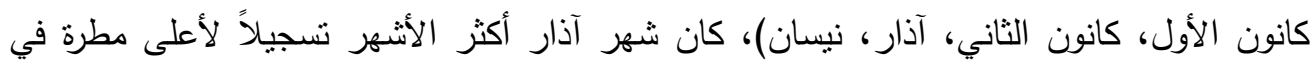
العراق، ثم شهر نيسان بالمرنبة الثانية.

\section{Daily rainfall recorded in Iraq (Synoptic Study)}

Dr . Malik Nasser Abbood Al-Kenani

The fall of the highest daily rainfall in Iraq resulting from the repetition of three depressions air , namely: low air Mediterranean air and low integrated air and low-Sudanese, and found that the quantities of the highest flask in Iraq vary between the region and the other because of the nature of the weather depressions affecting them and her paths and weather conditions prevailing with patterns piezoelectricity accompaniment in the upper layers of the atmosphere. And appeared to be the highest recorded flask in Iraq for the period (1971-2012) was $114 \mathrm{~mm}$ in Amara station in the day ( 01/03/1999 ), also shows that the highest flask was limited to five months ( November, December, January, March , April ), it was the month of March more months recording the highest flask in Iraq, then the month of April in second place . 


\section{لمقدمة Introduction}

يُقصد بالأمطار القياسية اليومية أعلى مطرة (Highest Rain) يومية منساقطة خلال

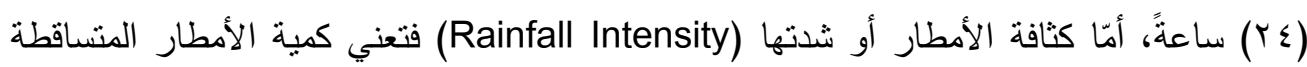

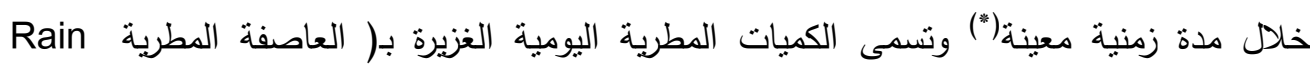

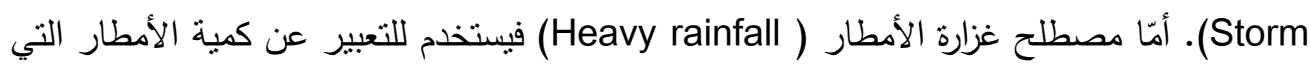

تزيد عن (^) ملم/يوم واذا ما قلت عن هذه الكمية فتعد أمطار خفيفة (Ramzah,2005,p82).

و تتصف الأمطار في العراق، بأنّها غير منتظمة في تساقطها وشدثّها وكمياتها، فقد تسقط كمية أمطار في يوحٍ واحدٍ تزيد على أمطار شهر أو سنة، وهذا ما بعطي أهمية لهذه الظاهرة

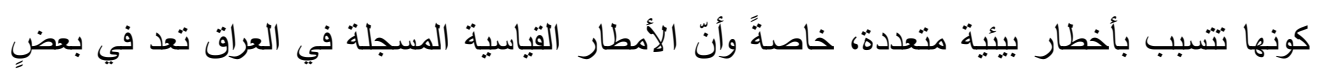
منها شاذة من حيث كمياتها المطرية، فنجد بعض المحطات ذات ذات كميات مطرية سنوية قليلة ولكنها

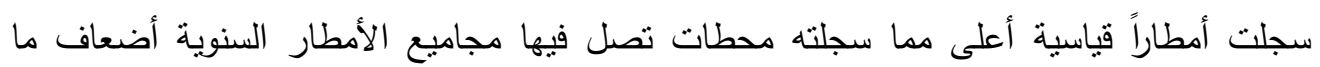
تسجله تلك المحطات، وفي المقابل نجد أنّ بعض المحطات ذات أمطار أعلى ولكنها لم تسجل

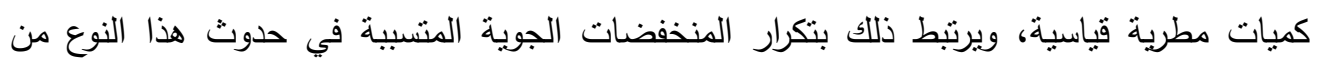

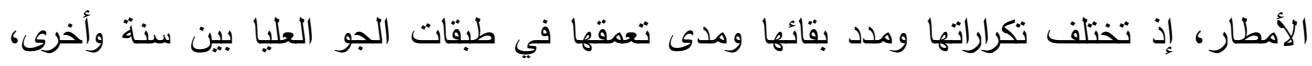

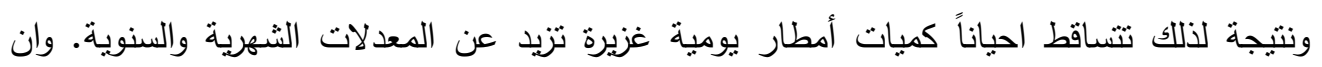

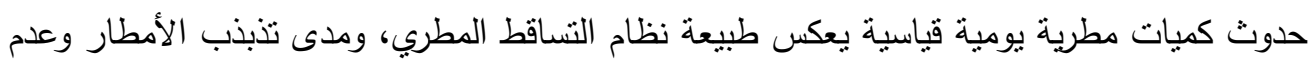

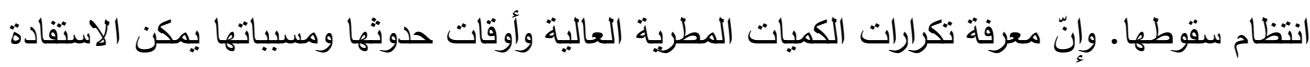

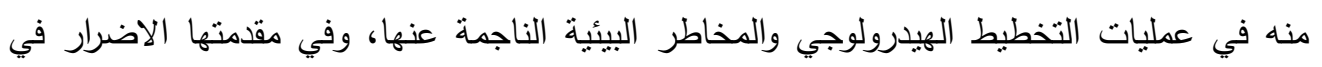
الزراعة وما يترتب عليها من خسائر اقتصادية كبيرة فضلاً عن النشاطات البشرية المنأثرة بالأمطار .

(*) تستخرج كثافة الأمطار (Rainfall Intensity) باستخدام المعادلة الاتية: كثافة الأمطار = كمية الأمطار / المدة

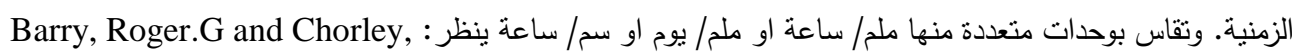
Richard.D, Atmosphere, Weather And Climate, ${ }^{8}$ Edition, Rout ledge, London, p.75,2003.

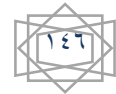


يهدف البحث إلى دراسة أعلى الكميات المطرية اليومية المنساقطة في العراق، ومعرفة أسباب

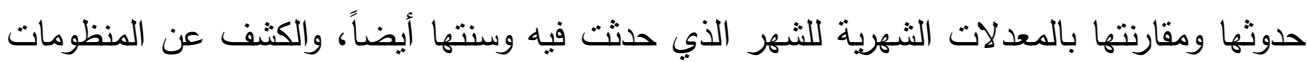

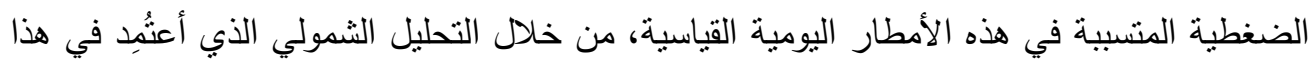

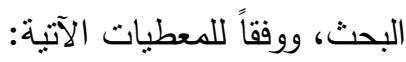

1- تم الاعتماد على المعطيات المطرية المسلة في (·r) محطة مناخية موزعة بشكل مثالي

$$
\text { في العراق. ينظر خريطة (1). }
$$

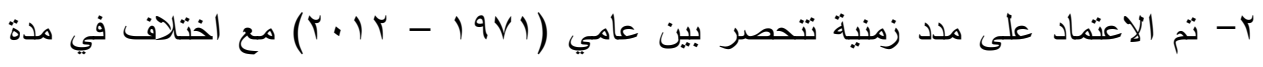

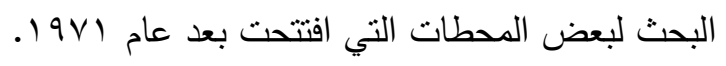

r- لغرض الكثف عن المنظومات الثمولية السائدة أثناء سقوط الأمطار القياسية، تم تحليل

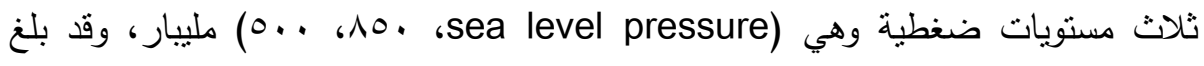

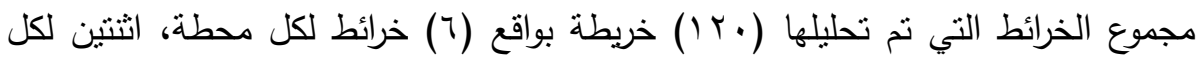

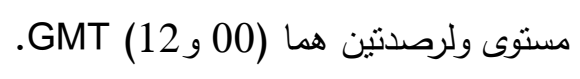

وقد جاءت مشكلة البحث على شكل مجموعة التساؤلات العلمية الآتية:

1- كيف تتوزع الأمطار القياسية زمانياً ومكانياً في العراق؟

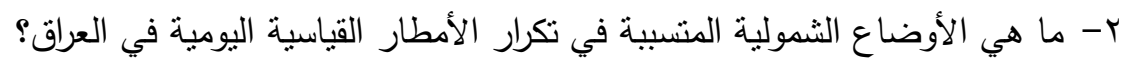
أمّا فرضيات البحث فقد تم وضع مجموعة من الفروض العلمية التي حاولنا من من خلالها معالجة مشكلة البحث وهي: فيات

$$
\text { 1- إنتاين كميات الامطار القياسية اليومية زمانياً ومكانباً. }
$$

r- يؤثر نكرار المنخفضات الجوية الجبهوية في تحقيق أعلى مطرة في العراق.

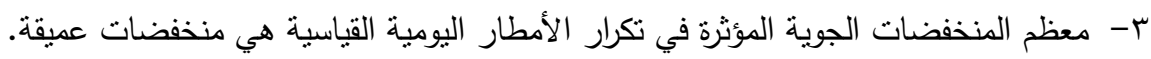

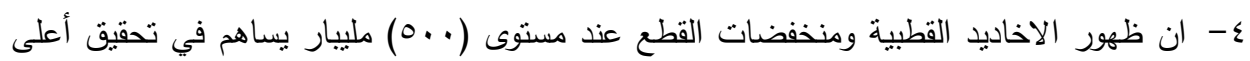
مطرة. ه- نتباين كميات الأمطار القياسية بحسب المسالك التي تتخذها المنخفضات الجوية. 
العــــــد الثــامن عشــر

مجلــــة كليــــة التربيــــة

\section{خريطة (1) \\ المحطات المناخية المشمولة بالبحث}

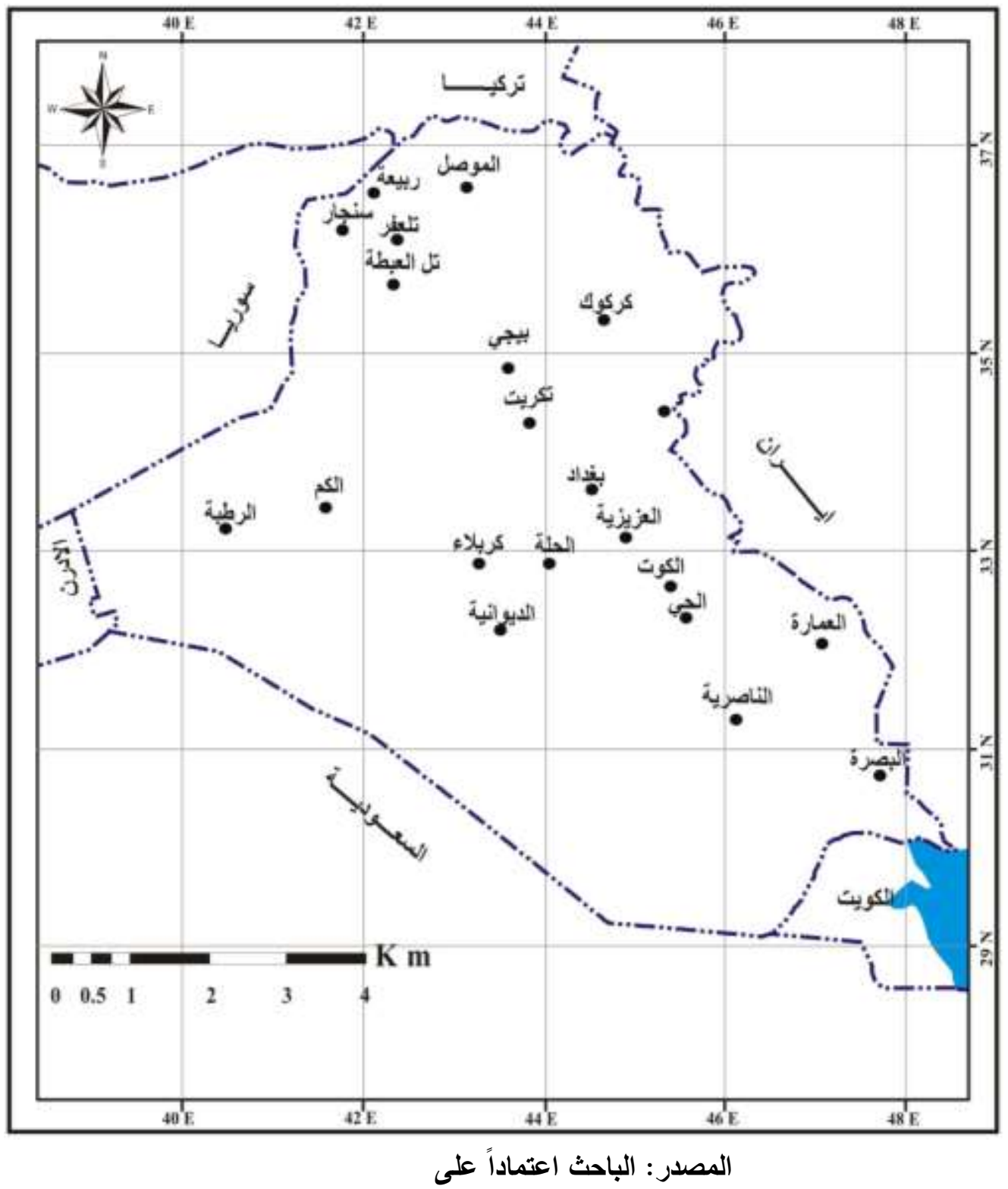




\section{مجلـــة كليـــة التريبـــة}

http://meteoseism.gov.iq

أولاً: التباين الزماني الثهري للأمطار اليومية القياسية في العرلق.

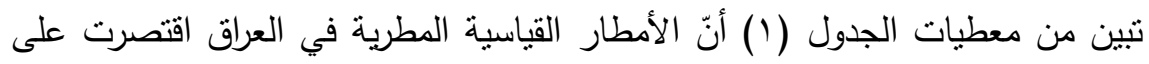

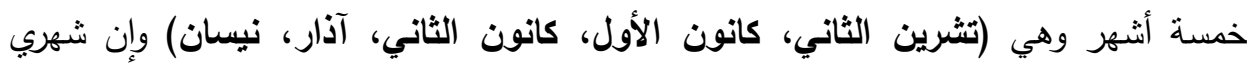
تثرين الأول الذي يمثل بداية الموسم المطري في معظم محطات الرصد الجوي في العراق

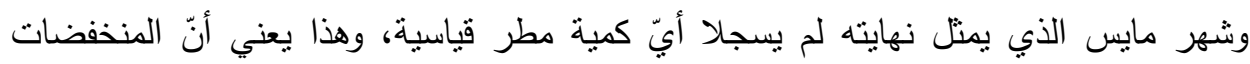

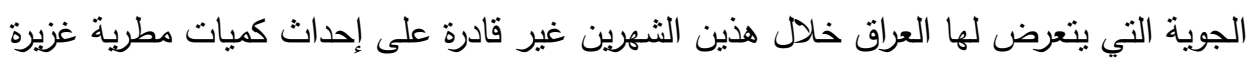
أو قياسية بسبب ضحالتها.

وكما يظهر أيضاً من الجدول (1) فأنّ (•؛\%\%) من نكرار نتلك الأمطار حدثت خلال

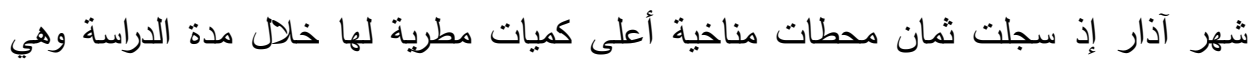

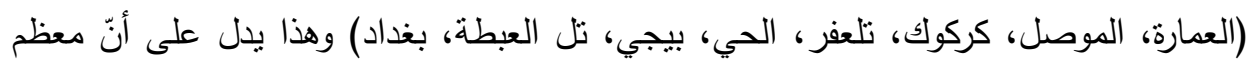

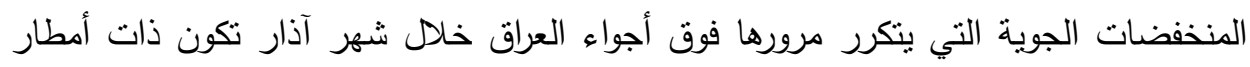

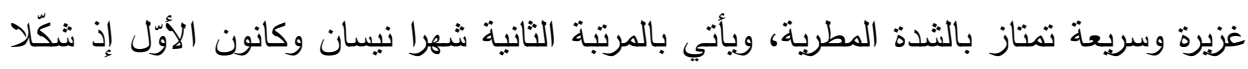

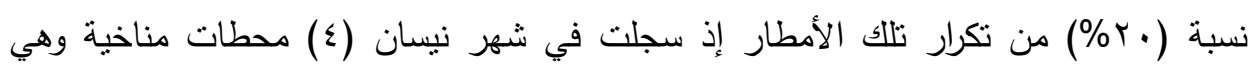

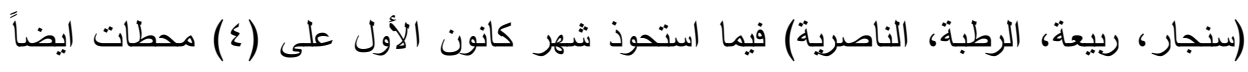

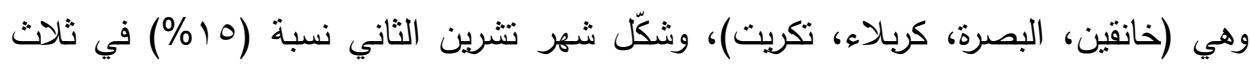

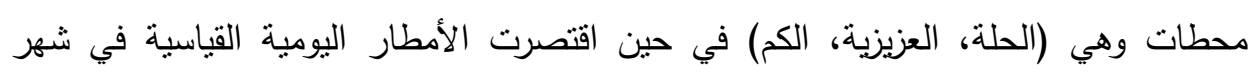
كانون الثاني في محطة الكوت وبواقع (0\%) وهي أقل نسبة مسجلة بين الثهور الخمسة.

ويتضح مما تقدّم أن الأمطار المتساقطة خلال شهري الربيع (آذار ونيسان) تتسم بالثدة

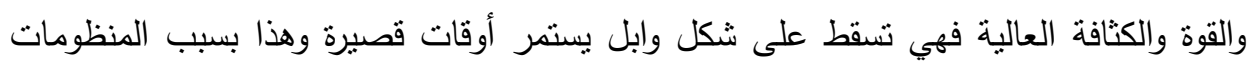

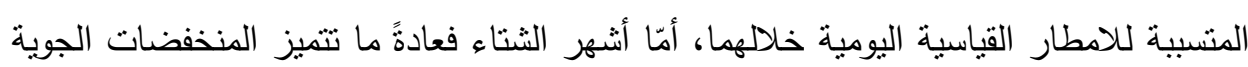
بطول أعمارها ويكون النساقط المطري فيها على شكل رذاذ ويكون خفيفاً احياناً. 
العــــــد الثــامن عشــر

مجلــــة كلبــــة التربيـــة

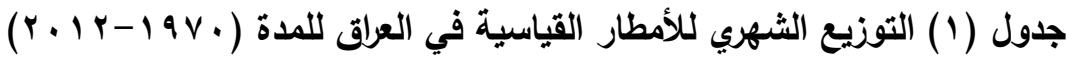

\begin{tabular}{|c|c|c|c|}
\hline المحطات & $\%$ & المحطات & الشهر \\
\hline الحلة،العزيزية، الكم & $10 .$. & $r$ & تشرين \\
\hline خانقين، البصرة، تكريت، كريلاء & $r \cdot$. & $\varepsilon$ & كانون الاول \\
\hline الكوث & ๑.. & 1 & كانون \\
\hline العمارة، الموصل،كركوك، تلعفر، الحي، بيجي، تل العبطة، & $\varepsilon \cdot \ldots$ & $\wedge$ & آذار \\
\hline سنجار،ربيعة، الرطبة، الناصرية & $r \cdot$. & $\varepsilon$ & 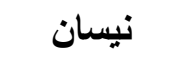 \\
\hline & $\cdots$ & $r \cdot$ & المجموع \\
\hline
\end{tabular}

المصدر: الباحث اعثماداً على جدول (r)

ثانياً: التباين المكاني الكمي للأمطار القياسية اليومية في العراق

لاتعتمد كمية الأمطار اليومية القياسية المنساقطة في العراق على المجموع السنوي

للتساقط المطري، فليس المحطات الأكثر مطراً هي من نسجل كميات مطرية يومية قياسية، فنلاحظ أغزر مناطق العراق مطراً لم تنجل أعلى كميات مطرية يومية بالمقارنة بمحطات أمطارها لا تتعدى ( • (10)ملم. 
إنّ بعض كميات الأمطار اليومية القياسية المتساقطة في بعض المحطات فاقت كمية الأمطار المنساقطة في بعض السنوات، بمعنى أنّ مطر يوم واحد زاد عما سجلته هذه المحطة خلال موسم مطري كامل (أي ثمانية أشهر) فمثناً يلاحظ أن محطة العمارة سجلت تشاقطاً مطرياً مقداره (ع (1) ملم في يوم (1/ / (999/1) زادت هذه الكمية على ما سجلته هذه المحطة

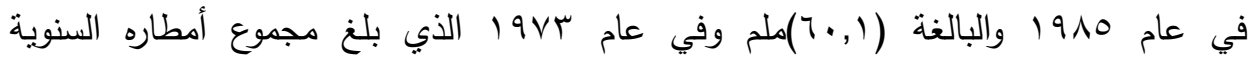

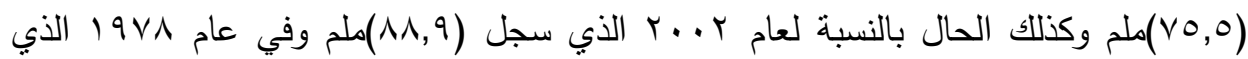
سجل ( V,^ • ( ) ملم. وينطبق الحال أيضاً على بعض المحطات، ومنها محطة الحلة التي بلغت

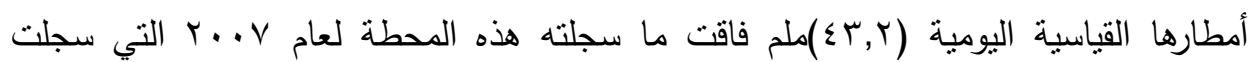
(اء) ملم. وهذا يؤكد أنّ الأمطار المتساقطة في جميع مناطق العراق لا تتصف كمياتها بالانتظام بل أنّ التذبذب المطري هو السمة البارزة في نظام سقوط الأمطار فيها، وتشتد فعالية التذبذب المطري كلما قلّ المجموع السنوي للأمطار، أيّ أنّ نسبته نرتفع في المناطق الجنوبية

$$
\text { والوسطى من العراق وتقل في المحطات الثمالية. }
$$

وتتباين الكميات المطرية اليومية الأعلى في العراق بين محطات الرصد الجوي المعتمدة في

الدراسة ومن خلال الجدول (r) والشكل (1) أيضاً يظهر أنّ أعلى الكميات المطرية تم تسجيلها في شهري آذار ونيسان فقد جاءت ست محطات بالمراتب الست الأولى كانت أعلى كمياتها المطرية في هذين الثهرين اذ تصدّرت محطة العمارة جميع محطات الدراسة بأعلى مطرة بلغت (ع ا ا) ملم في

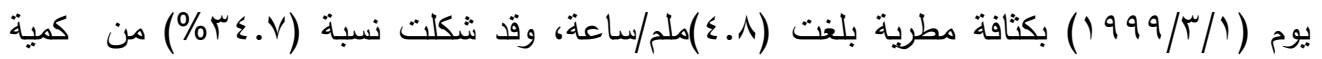

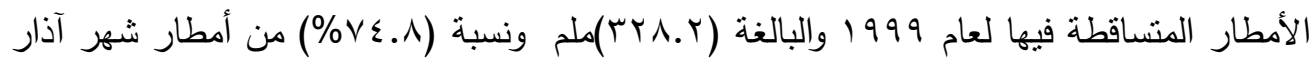
لنفس السنة والبالغة (0.0 ( \% \%)ملم. تلتها في المرتبة الثانية محطة الموصل التي كانت أعلى كمية

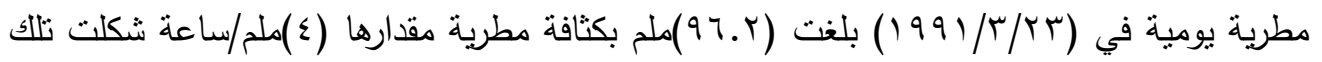

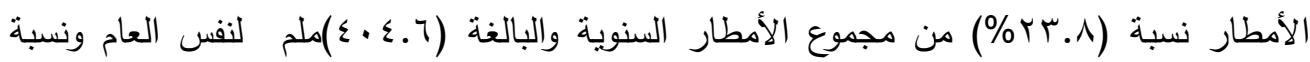

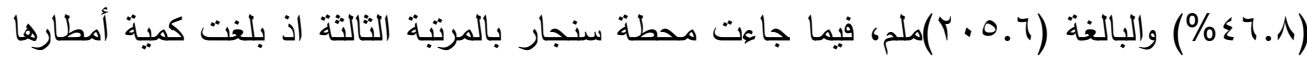

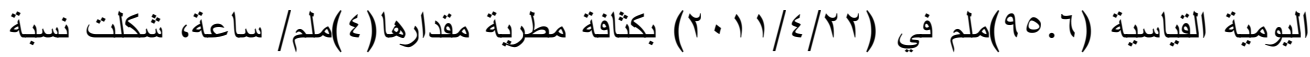

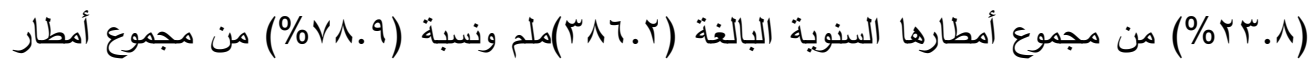

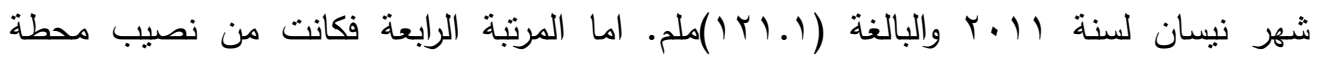

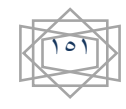




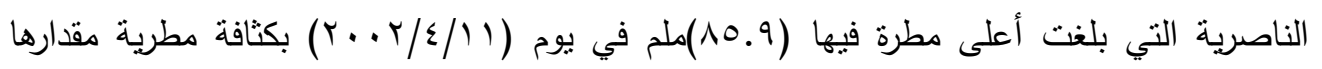

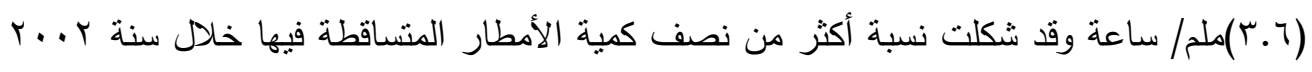

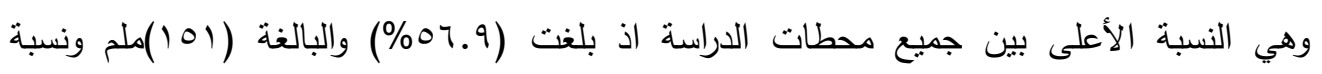

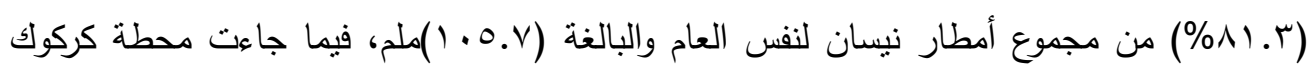

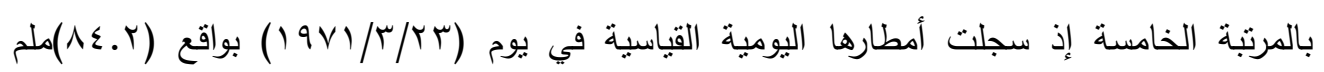

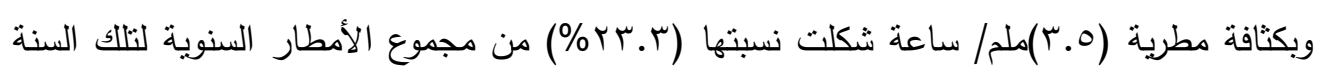

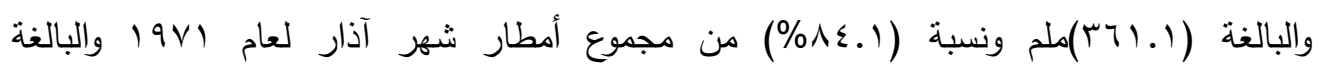
(1. . (1)ملم، أمّا المحطة السادسة من حيث التزتيب فهي محطة ربيعة الني سجلت أعلى أمطارها

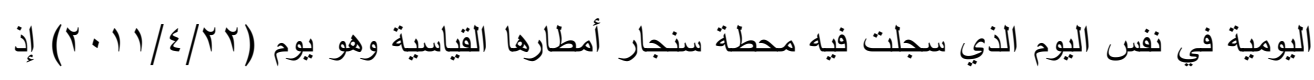

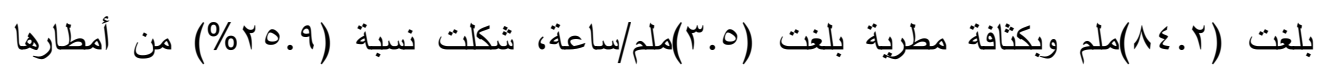

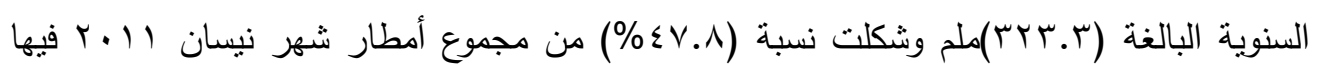

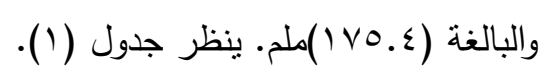

ويبقى شهر آذار مسيطراً على الكميات المطرية الأعلى بين شهور السنة في بعض وهل

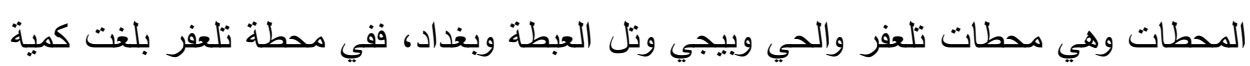

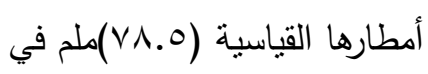




\begin{tabular}{|c|c|c|c|c|c|c|c|c|c|c|c|}
\hline سماعة المطر & شهر التصاقط الذي & اليوم & الثطري & التي حدثت التساقط فيها & 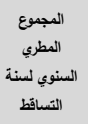 & 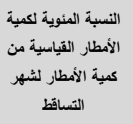 & الألمطبة المئوية لكمية الأميارية من & المـــــة & مطرة & المحطة & $ت$ \\
\hline$\{. \wedge$ & آذار & الأول & 10r.o & 1999 & rYA.r & $v \varepsilon . \wedge$ & $r \leq . V$ & $\begin{array}{l}-1941 \\
r .14\end{array}$ & $11:$ & العمارة & 1 \\
\hline$\varepsilon$. & آذار & والعثشرين & Y.0.T & 1991 & $\leq . \leq .4$ & $\lfloor 4.1$ & rr.A & $\begin{array}{l}-19 v 1 \\
\text { r.lu }\end{array}$ & १५. & الموصل & 2 \\
\hline$r .4$ & نيسان & الحادي & $1.0 . v$ & $r \ldots r$ & 101 & A I.r & 04.9 & $\begin{array}{l}-1941 \\
r .14\end{array}$ & 10.9 & الناصرية & 4 \\
\hline r.o & آذار & والعشرين & $1 \ldots 1$ & $19 \times 1$ & mו1. & $\wedge \leqslant .1$ & rt.r & $\begin{array}{l}-19 v 1 \\
r .1 r\end{array}$ & A $\varepsilon . Y$ & كركوك & 5 \\
\hline r.o & نيسان & والعشرين & 1vo.s & r.ll & rutr.r & $\{v . \wedge$ & ro.9 & $\begin{array}{l}-19 \times 0 \\
r .1 r\end{array}$ & Ar.A & ريبعة & 6 \\
\hline$r .1$ & كانون الاول & العاشر & vv.e & 1999 & rRA.T & $90 .$. & $r \cdot . A$ & $\begin{array}{l}-19 v 1 \\
r .1 r\end{array}$ & vr.t & بصرة & 9 \\
\hline r.. & آذار & والثشرين & 117.0 & lavr & ra. & 7.9 & $r \leqslant .0$ & $\begin{array}{l}-19 v 1 \\
r .1 r\end{array}$ & $v_{1}$ & الحي & 10 \\
\hline$r . \wedge$ & نيسان & العاشر & $1 \times r .9$ & 1981 & $1 \times 4.4$ & or.r & ro.s & $\begin{array}{l}-19 v 1 \\
r .1 r\end{array}$ & 11 & الرطبة & 11 \\
\hline ז. & آذار & عثر & $\wedge \wedge .9$ & $r \ldots r$ & Pl1.s & 79.8 & ra.r & $\begin{array}{l}-1994 \\
r .14\end{array}$ & ir & بيجي & 12 \\
\hline Y. T & آذار & عشر التاسع & १५. & $r \ldots r$ & ris.v & $\Upsilon \leftarrow .$. & $19 . r$ & $\begin{array}{l}-199 r \\
r .1 r\end{array}$ & 7.4 & العبطة & 13 \\
\hline r.\& & آذار & عشر الخامس & va.० & lavr & 191.4 & vr.e. & $r \cdot . r$ & $\begin{array}{l}-1941 \\
\text { r.lr }\end{array}$ & $\bullet \wedge$ & بغاد & 14 \\
\hline
\end{tabular}


العــــــد الثــامن عشــر

مجلـــة كليــــة التربيـــة

\begin{tabular}{|c|c|c|c|c|c|c|c|c|c|c|c|}
\hline r. & كانون الاول & الثاني & VY.V & 1994 & rAY & va.1 & r... & $\begin{array}{l}-19 \times 9 \\
r .14\end{array}$ & ov.o & تكريت & 15 \\
\hline r.. & تثرين الثاني & والعثريني & v..r & $199:$ & $10 V . A$ & $r . r$ & $r \ldots$ & $\begin{array}{c}-199 \$ \\
r .14\end{array}$ & \&v.r & الغزيزية & 16 \\
\hline 1.9 & كانون الثاني & عثر & ؛ $0 . v$ & $199 \mathrm{~V}$ & int.r & 99.1 & $r \leqslant . V$ & $\begin{array}{l}-1914 \\
r .14\end{array}$ & ؛ $0 . r$ & الكوت & 17 \\
\hline 1.1 & تشرين الثاني & والعثرين & $r \wedge .0$ & $r \ldots r$ & $1+4.0$ & 4.1 & rr. & $\begin{array}{l}\text {-19v9 } \\
\text { r.up }\end{array}$ & $\{r . r$ & الحلة & 18 \\
\hline 1.v & تثرين الثاني & عثر الساس & 90.9 & 1998 & 101.r & $\{1.9$ & ro.s & $\begin{array}{l}-19 \times 9 \\
\text { r.14 }\end{array}$ & $\Leftrightarrow . . r$ & الكم & 19 \\
\hline 1.4 & كاون الاول & الثامن & $r^{\wedge} .9$ & 1994 & ,... & 14.9 & rr.A & $\begin{array}{l}-1984 \\
\text { r.14 }\end{array}$ & 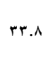 & كريلاء & 20 \\
\hline
\end{tabular}

المصدر : الباحث اعتمادأ على: وزارة النقل والمواصلات، الهيأة العامة للأتواء الجوية والزرصد الززلزالي العراقية، قسم المناخ (بيانات غير منشورة)

كثافة الأمطار = كمية الأمطار المتساقطة/ المدة الزمنية 
العــــــد الثــامن عثــر
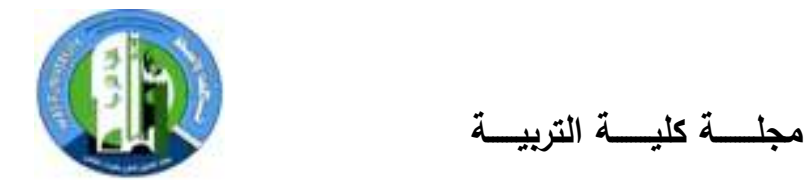

شكل (1) الأمطار اليومية القياسية في العراق للمدة

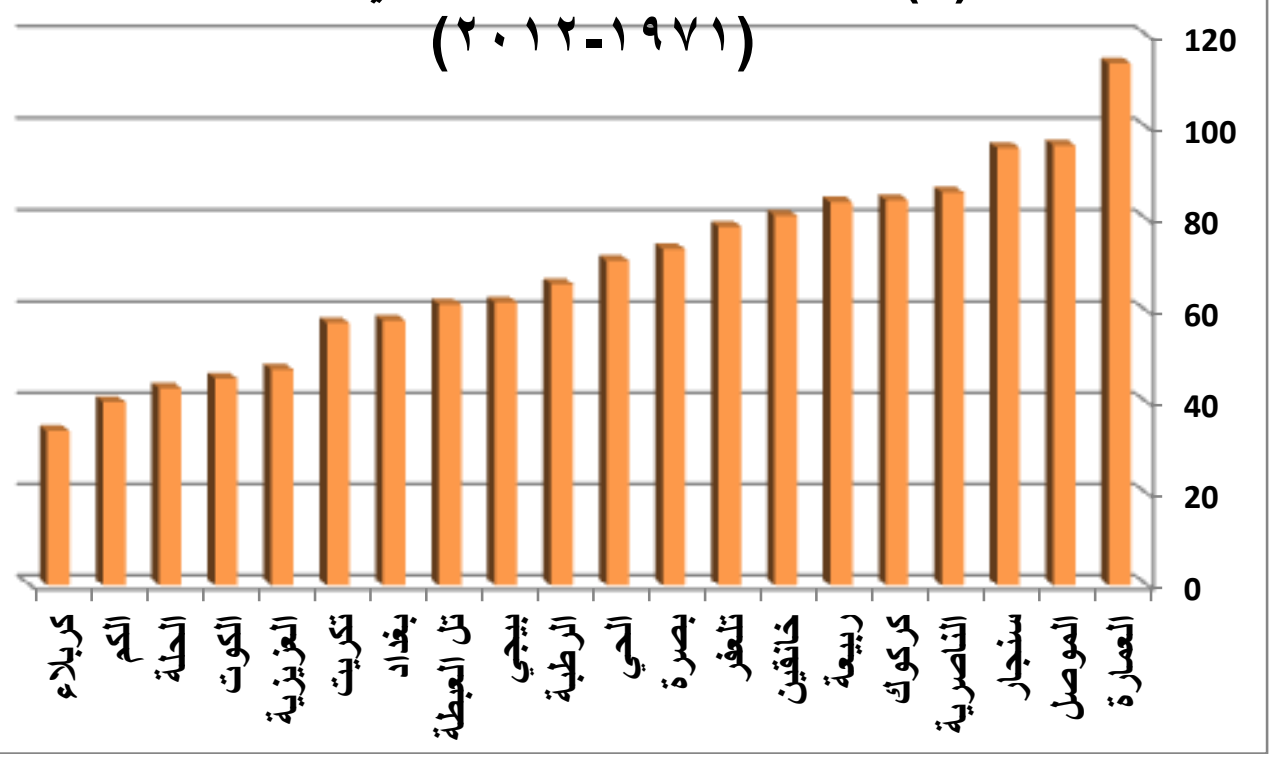

المصدر: الباحث اعتماداً على جدول (r)

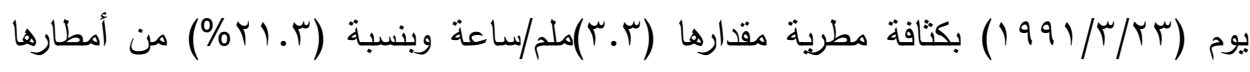

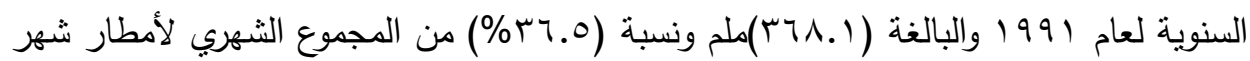
آذار لنفس السنة والبالغة (10.1 (Y)ملم، وفي محطة الحي التي سجلت أعلى أمطارها اليومية في

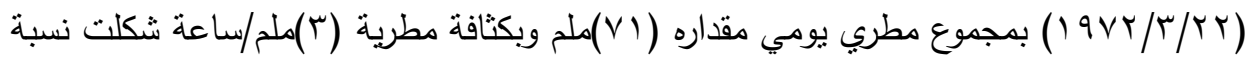

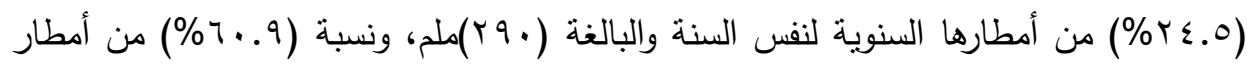
شهر آذار لنفس السنة والبالغة (1.0 (1) (ملم، وكذلك الحال بالنسبة لمحطة بيجي التي سجلت

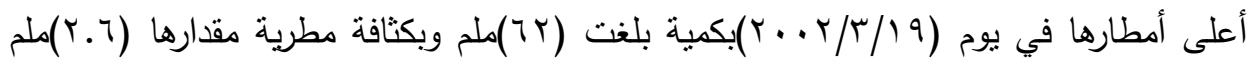

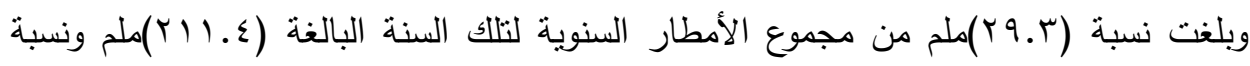

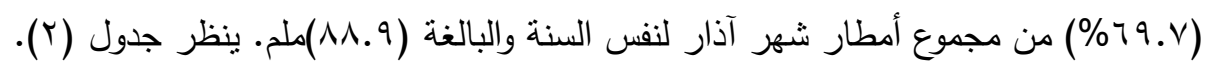


وقد اقتصر التساقط في أشهر الثتاء على شهري كانون الأول وكانون الثاني فكانت أمطارهما القياسية اليومية اقل مما سجله شهرا الربيع (آذار ونيسان) اذ تمناز أمطارهما باستمرارية أطول وشدة اقل، ولذلك جاءت أمطارها اليومية بكميات اقل مما سُجل في المحطات الأخرى التي سجلت أعلى أمطارها في شهري آذار ونيسان، ما عدا محطتي خانقين والبصرة اللنان سجلتا أعلى مطرة لهما في شهر كانون الأول، وفاقت المحطات التي سجلت أعلى أمطارها في شهري آذار ونيسان، اذ تقوقت محطة خانقين على محطات تلعفر والحي والرطبة وبيجي وتل العبطة وبغداد، ومحطة البصرة تفوقت على جميع المحطات التي تفوقت فيها محطة

خانقين ما عدا محطة تلعفر • ينظر جدول (r).

وعلى هذا الأساس بيلاحظ أن محطة خانقين التي جاءت بالمرتبة السابعة بين جميع

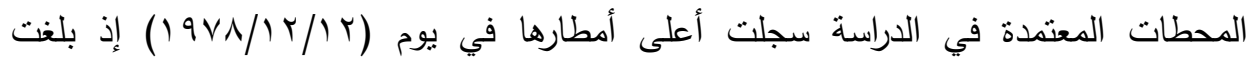

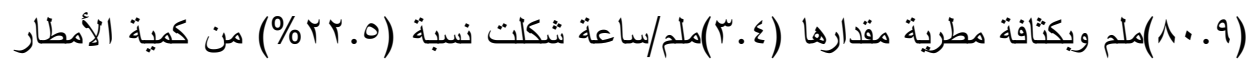

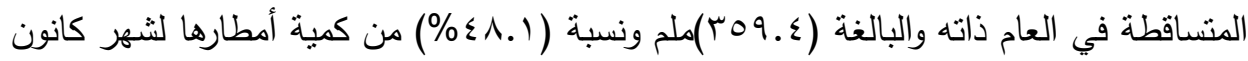
الأول ولنفس السنة والبالغة (r.14 (1)ملم. كما سجلت محطة البصرة أعلى أمطارها في شهر كانون الأول في يومه العاشر من عام (999 ()) بواقع (T.T/Vملم وبكثافة مطربية مقدارها

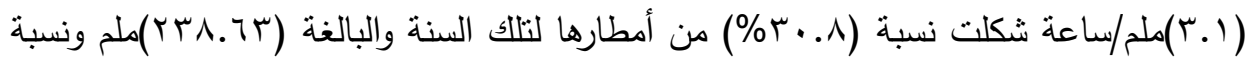
(90\%) من أمطارها في شهر النساقط لنفس السنة والبالغة كميته (V.0)ملم. وقد سجلت محطة كربلاء اقل أعلى مطرة بين محطات الدراسة بلغت (^.بr)ملم بكثافة مطرية بلغت (ع ( )ملم/ ساعة وبنسبة (1.بr\%) من مجموع الأمطار السنوية لها في تلك السنة والبالغة

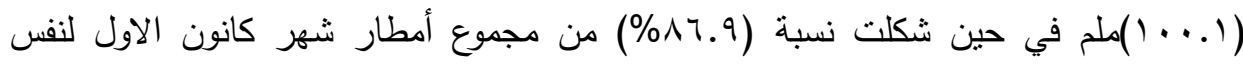
السنة. ينظر جدول (r). (1) - (ب) ثالثاً: التحليل الشمولي للمنظومات الجوية المتسبية في الأمطار اليومية القياسية في العرلق ان الأمطار الكثيفة في مناطق العروض الوسطى (ومنها العراق) ترتبط بحركة المنظومات الإعصارية المنكونة في مناطق نشوء الجبهات (Cyclogenesis) التي تتسبب تساقط كميات Delrieu., ) (Thunderstorms) مطرية غزيرة وتصاحبها احياناً عواصف رعدية 
2005.p5)، وقد أظهر التحليل الثمولي لخرائط الطقس السطحية أنّ هناك ثلاثة منخفضات

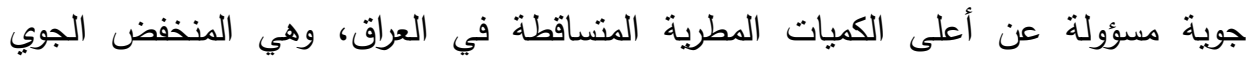
المتوسطي والمنخفض الجوي المندمج والمنخفض الجوي السوداني، وذات تلك المنخفضات المئه

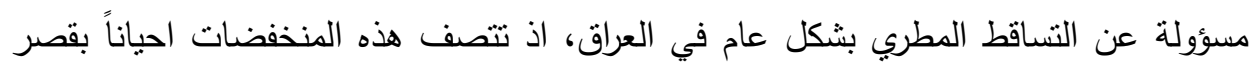

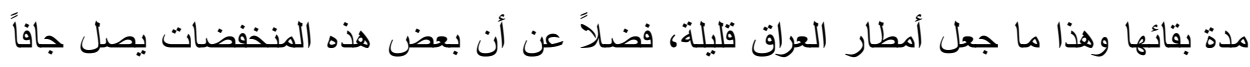

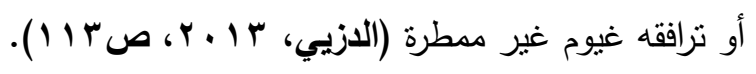

وقد تباينت معدلات تكرار هذه المنخفضات الثلاثة، كما أنّ ظهورها فوق أجواء كل

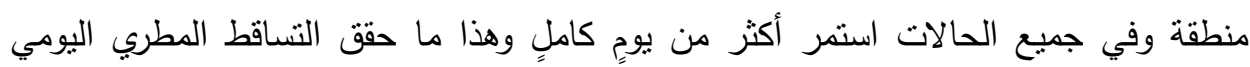

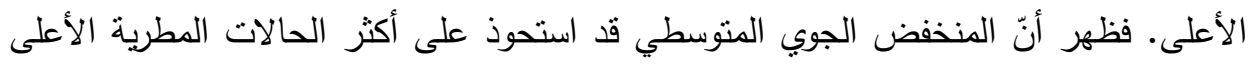

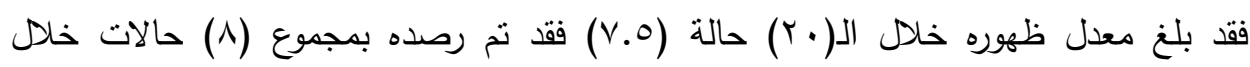

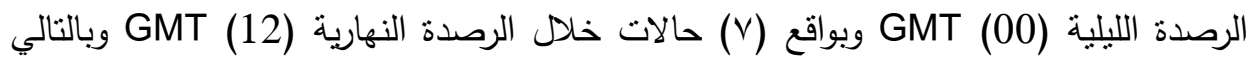

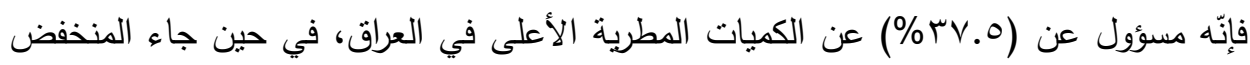

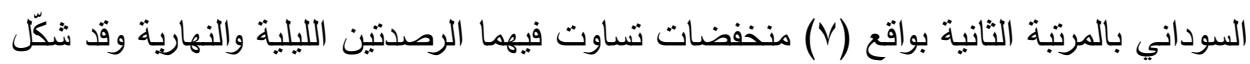
نسبة (0r\%) من مجموع الكميات المطرية الأعلى في العراق، في حين جاء المنخفض المندمج

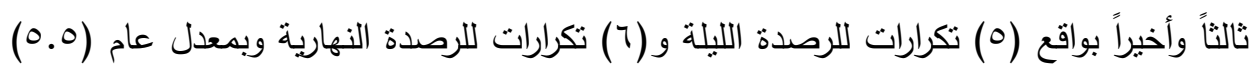

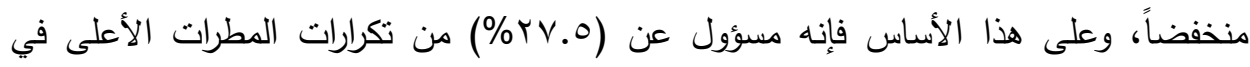
المحطات المدروسة. ينظر جدول (r).

وقد تيّيّ أنّ حوالي (•^\%) من المنخفضات المتوسطية كانت عميقة وظهرت امتداداتها

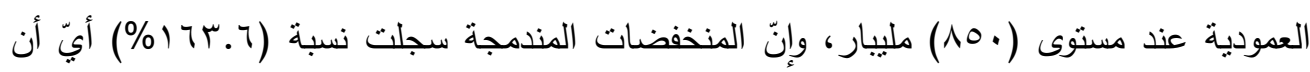

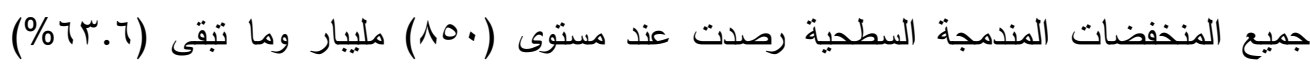

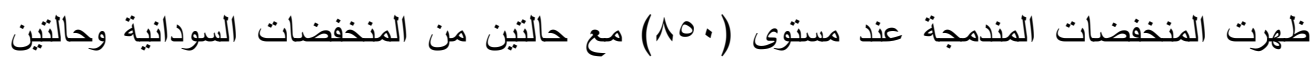

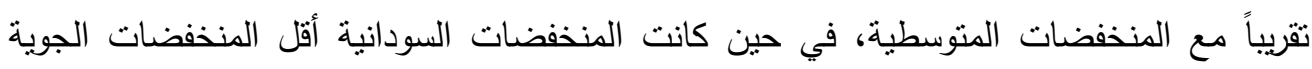

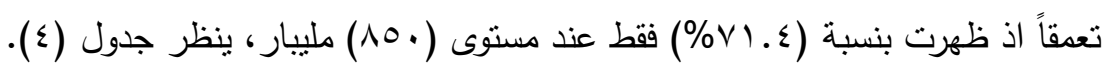

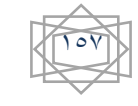




\section{مجلــــة كليــــة التربيــــة}

ولطبيعة حركة المنخفضات الجوية المتحكمة في كميات الأمطار في العراق ومدى تعمقها وطبيعة الظواهر المرافقة لها في طبقات الجو العليا، فقد تباينت تأثنراتها في تسجيل المطرات الأعلى في العراق، وكما يظهر من جدول (0)، فقد ثنّن أنّ المنخفض السوداني أعلى معدل من حيث كمية الأمطار المرافقة له في جميع الحالات التي تم رصده فوق أجواء المحطات التي سجلت مطراً قياسياً اذ بلغ (V) (V) ملم، وقد تبيّن أنّ تأثنيره يكون أقوى وأثند غزارة بالنسبة للأمطار المسجلة خلال شهري

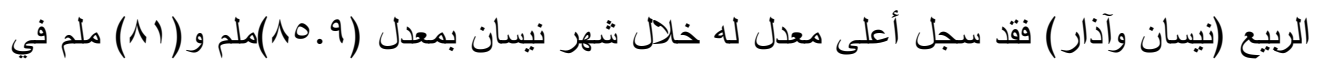

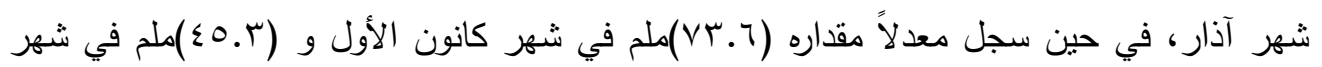
كانون الثاني، وحلّ المنخفض المتوسطي بالمرتبة الثانية اذ بلغ المعدل العام للأمطار القياسية اليومية

جدول(ץ) تكرار المنخفضات الجوية المتسببة في أعلى الكميات المطرية في العراق

\begin{tabular}{|c|c|c|c|c|}
\hline المجموع & السوداني & المنغفضمَج & المنخفض المتوسطي & $\begin{array}{l}\text { الرصدة } \\
\text { (GMT) }\end{array}$ \\
\hline$r$. & v & 0 & $\wedge$ & 00 \\
\hline$r$. & v & 9 & $v$ & 12 \\
\hline$r \cdot$ & V & 0.0 & V.o & المعدل \\
\hline $1 \ldots$ & ק & rV.o & rv.o & $\%$ \\
\hline
\end{tabular}

المصدر: الباحث اعتماداً على تحليل الخرائط الضغطية السطحية للحالات المدروسة

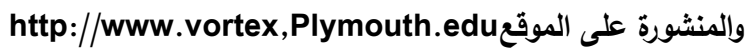


العـــــد الثـــامن عشـــر

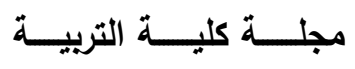

جدول(؛ ) تكرار المنخفضات الجوية المتسببة في أعلى الكميات المطرية في العرلق عند مستوى (•^م) مليبار

\begin{tabular}{|c|c|c|c|c|}
\hline المجموع & السوداني & المنغفضمَج & المنخفض المتوسطي & $\begin{array}{l}\text { الرصدة } \\
\text { (GMT) }\end{array}$ \\
\hline$r \cdot$ & 0 & 9 & 7 & 00 \\
\hline$r \cdot$ & 0 & 9 & 7 & 12 \\
\hline \multirow[t]{2}{*}{$r}$. & ○ & 9 & 7 & المعدل \\
\hline & VI. & 174.7 & ^. & نسبة التعمق \\
\hline
\end{tabular}

المصدر: الباحث اعتماداً على تحليل خرائط المستوى (•^م) مليبار للحالات المدروسة

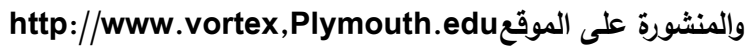

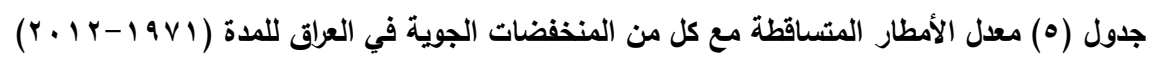

\begin{tabular}{|c|c|c|c|}
\hline المنخفض السوداني & المنذفمضج & المنخفض المتو & الشهر \\
\hline$\leq 0 . r$ & . & ov. $\theta$ & كانون \\
\hline A1.. & 11. & VT.r & آذار \\
\hline 10.9 & 74. & $\wedge 9 . \vee$ & نيسان \\
\hline . & $\varepsilon r . \Lambda$ & . & تثرين الث \\
\hline Vr. & - & ov.s & كانون الأ \\
\hline vi.e & $7 r . V$ & 79.0 & المعدل \\
\hline
\end{tabular}

المصدر: الباحث اعتماداً على جدول (ץ) وتحليل خرائط المستوى السطحي للحالات المدروسة. 


\section{مجلـــة كليــــة التربيـــة}

(79.0)ملم خلال كان أعلاها في شهر نيسان وهي الأعلى بين جميع المنخفضات والأشهر ( (19.v)

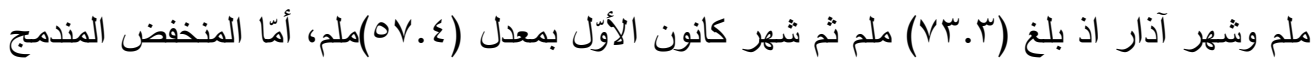

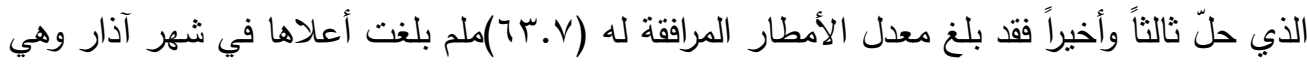

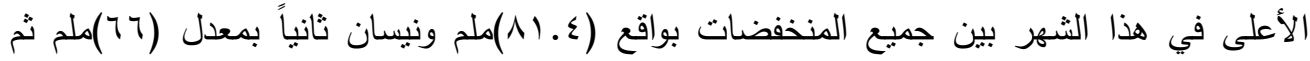

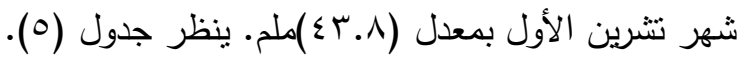

ويتضح مما تقدّم أنّ المنخفضات جميعها تسجل كميات مطرية يومية عالية خلال شهري نبسان وآذار على عكس أثنهر الثتاء التي تسجل كميات مطرية شهرية أعلى، وهذا ناتج من اختلاف نوعية التساقط المطرية وكثافته المرافق لهذه المنظومات الإعصارية اذ نكون على شكل زخات مطرية

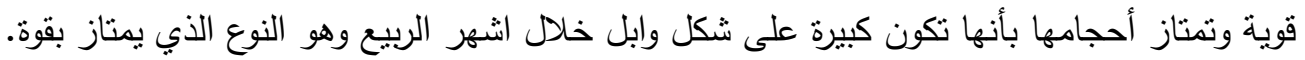

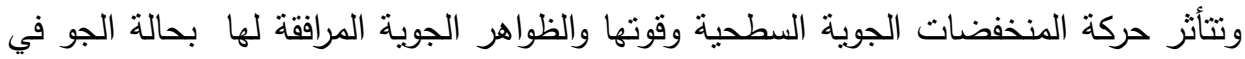
طبقات الجو العليا، لاسيما الأنماط الضغطية المختلفة المتتكلة عند المستويات الضغطية الدختلفة،

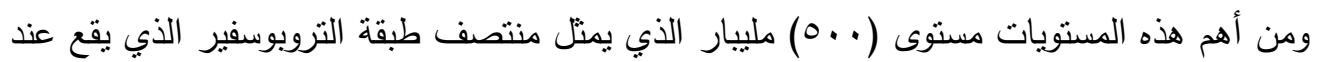

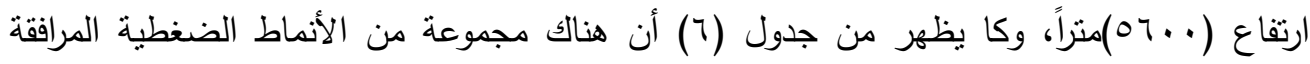

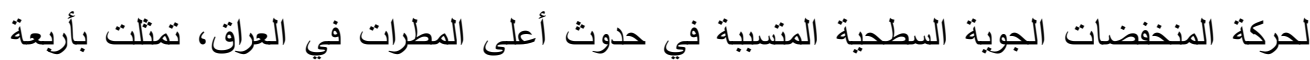
أنماط ضغطية وهي:

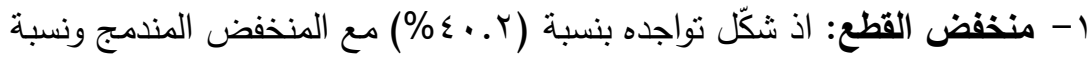

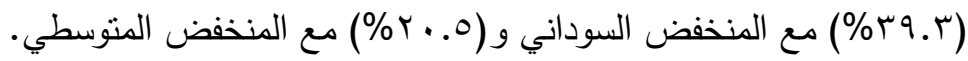

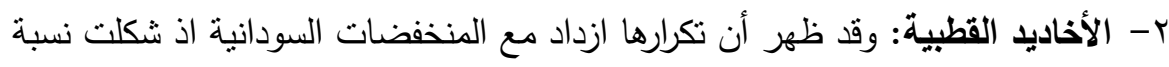

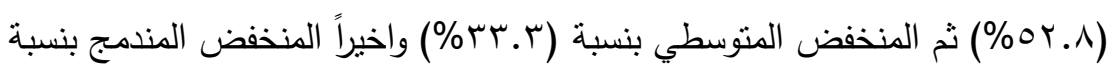
.$(\%, r .9)$

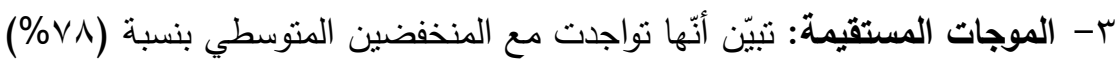

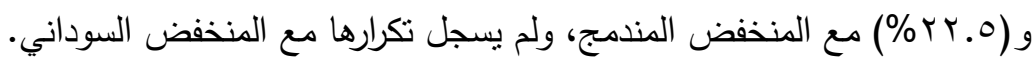
ع- المرتفع المداري: وقد سجّل أقل تلك الأنماط الضغطية بواقع حالة تكرار واحدة اقتصرت على المنخفض السوداني فقط.

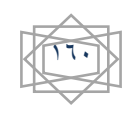


العــــــد الثـامن عشـــر

مجلــــة كليــــة التربيــــة

جدول ( 7 ) ظواهر الجو العليا عند مستوى ( . . •) مليبار المرافقة للمنخفضات الجوية السطحية

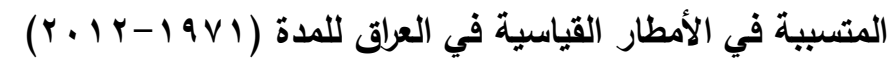

\begin{tabular}{|c|c|c|c|c|c|c|c|c|c|}
\hline \multicolumn{2}{|c|}{ المجموع } & \multicolumn{2}{|c|}{ المنخض } & \multicolumn{2}{|c|}{ المنخفض } & \multicolumn{2}{|c|}{ المنخقض } & \multirow{2}{*}{ الضغط } & \multirow{2}{*}{ الرصدة } \\
\hline$\%$ & التكرا & $\%$ & التكرار & $\%$ & التكرار & $\%$ & التكرار & & \\
\hline $1 \ldots$ & $\wedge$ & $0 .$. & $\varepsilon$ & TV.o & r & Ir.o & 1 & \multirow{3}{*}{ منخفض قطع } & 00 \\
\hline $1 \ldots$ & V & $r q$ & r & $\leq r . q$ & r & rq & $r$ & & 12 \\
\hline $1 \ldots$ & $V .0$ & rq.r & $r$ & $\varepsilon . r$ & r.. & $r . .0$ & 1.0 & & المعدل \\
\hline $1 \ldots$ & 7 & 0 . & r & 17.8 & $1 .$. & א.r" & $r$ & \multirow{3}{*}{ اخدود قطبي } & 0 \\
\hline $1 \ldots$ & 9 & 00.7 & 0 & 11.1 & $1 .$. & א.Tr & $r$ & & 12 \\
\hline $1 \ldots$ & $V .0$ & or.A & $\varepsilon$ & 17.9 & $1 .$. & ז.ז" & r.o & & المعدل \\
\hline $1 \cdots$ & 0 & . & · & $r . .$. & $1 .$. & $\wedge$. & $\varepsilon$ & \multirow{3}{*}{ موجة مستقبمة } & 0 \\
\hline $1 \ldots$ & $\varepsilon$ & . & . & ro.. & $1 .$. & Vo & $r$ & & 12 \\
\hline $1 \ldots$ & $\varepsilon .0$ & . & - & Yr.o & $1 .$. & $\vee \wedge$ & r.o & & المعدل \\
\hline $1 \ldots$ & 1 & $1 \ldots$ & 1 & . & . & . & . & \multirow{3}{*}{ مرتفع مداري } & 0 \\
\hline • & • & • & - & . & • & . & - & & 12 \\
\hline 0. & .0 & 0 . & .0 & - & . & - & . & & المعدل \\
\hline
\end{tabular}

المصدر: الباحث اعتماداً على تحليل خرائط ( . . ه) مليبار للحالات المدروسة والمنشورة على

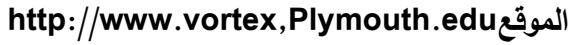




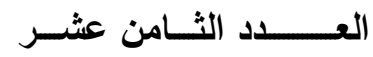

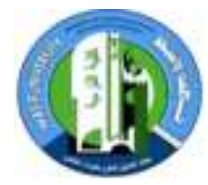

مجلـــة كليــة التربيــة

رابعاً: نماذج طقسية للحالات الثمولية المتسبة في الأمطار القياسية اليومية في العرلق

تم اختيار ثلاث نماذج طقسية للأوضاع الثمولية السطحية والعليا، نموذج لكل منظومة تسببت في الكمبات المطرية الأعلى، وهذه النماذج كانت بالثكل الاتئ لنادئ

1- المنذفض المتوسطي: إنّ نأثثر المنخفض الجوي المتوسطي في احداث كثافة مطرية عالية

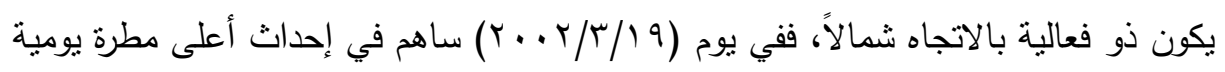

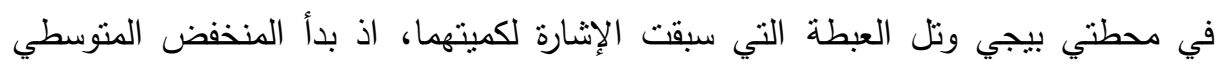

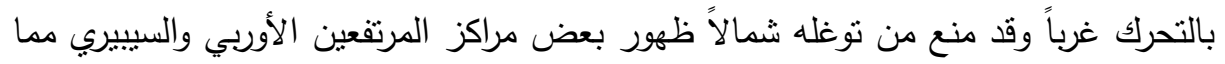

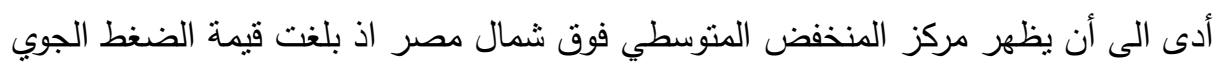

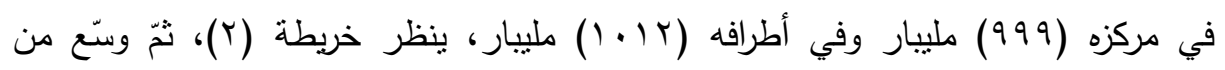

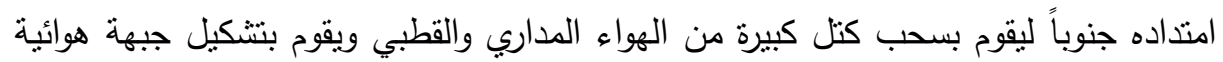

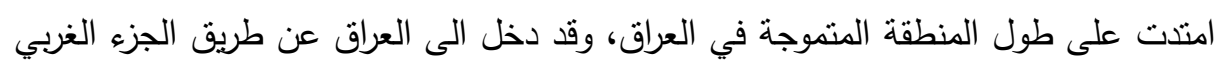

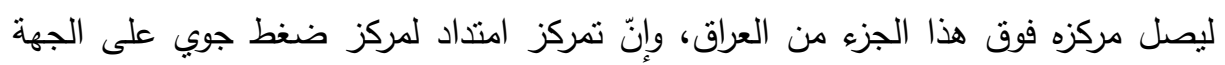

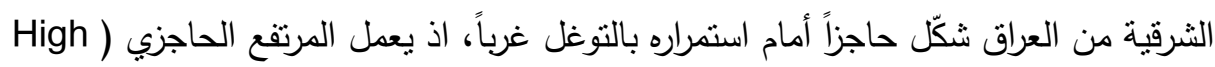
Blocking

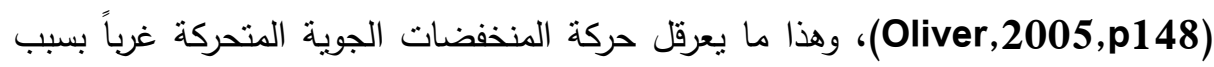

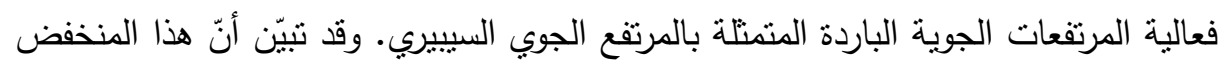

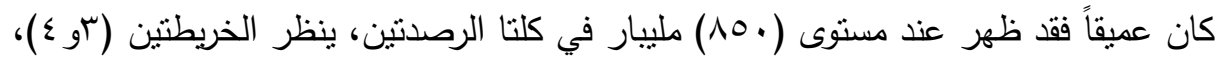

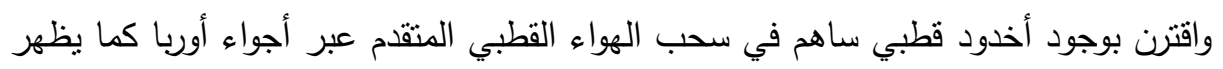
من الخريطنين (0و 7) مما ساهم في إحداث أمطار غزيرة في تلأك المحطنين.

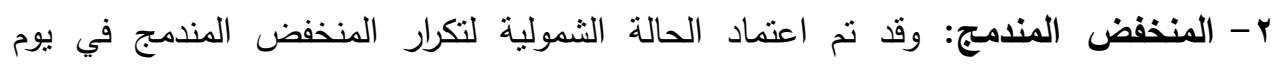

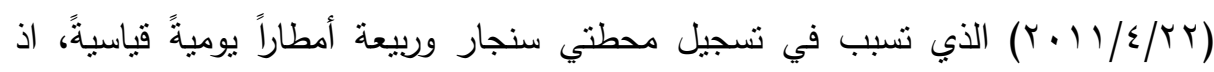

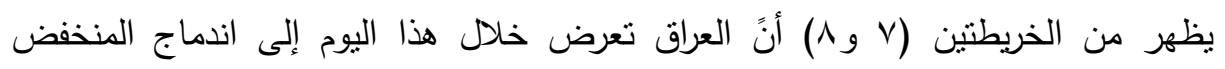

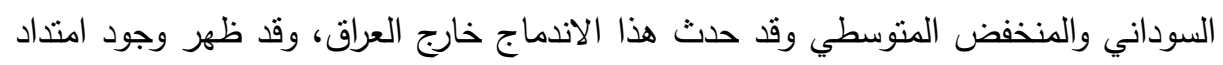

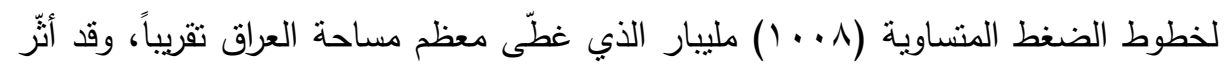
وجود أحد مراكز المرتفع السيبيري المتمركز فوق الجزء الغربي من إيران في أن يتغيّر مسار الهئ

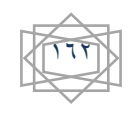




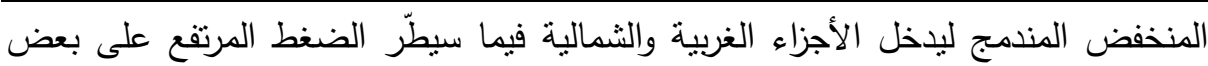

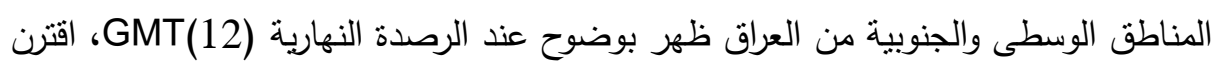

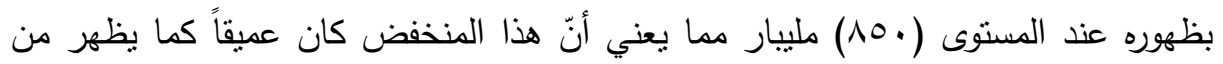

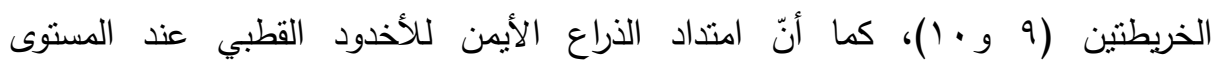

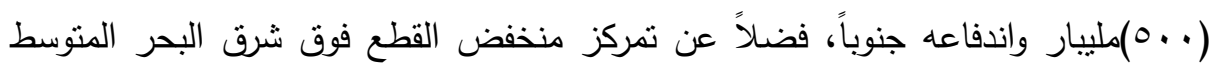

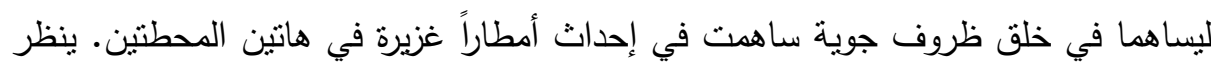

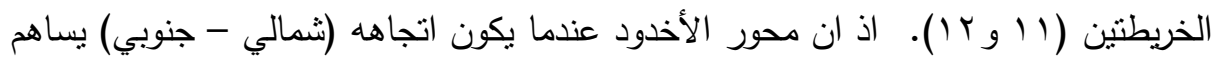

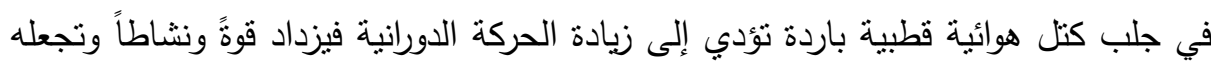
يتعمق ليصل حتى المنطقة الوسطى من العراق ويعمل على تتشيط المنظومة السطحية

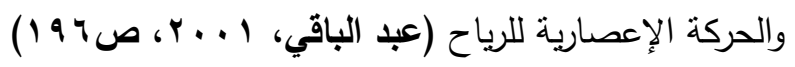

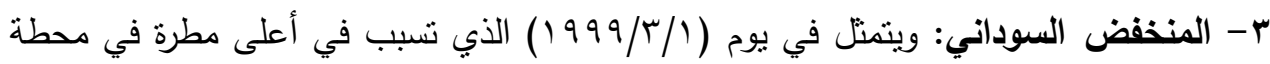

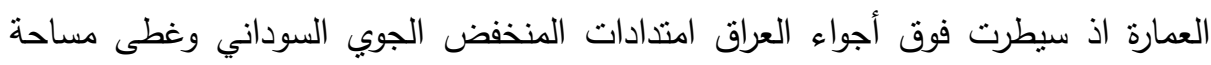

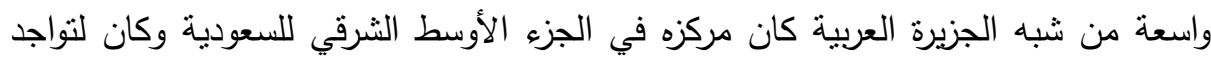

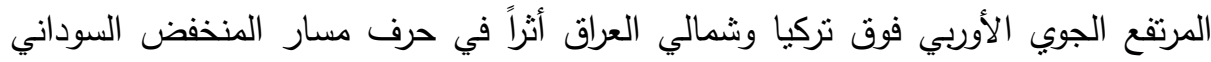

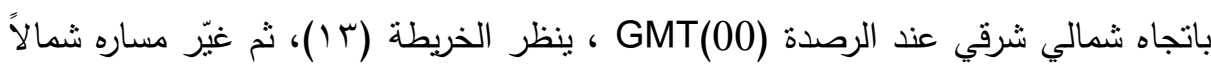

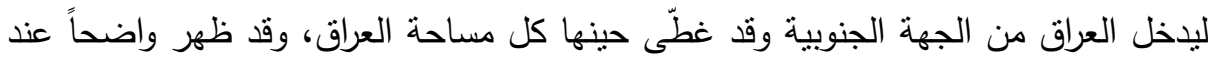

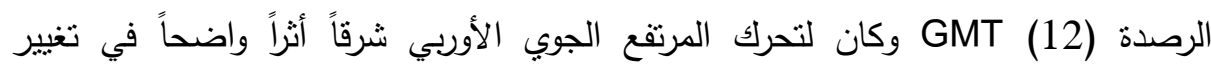

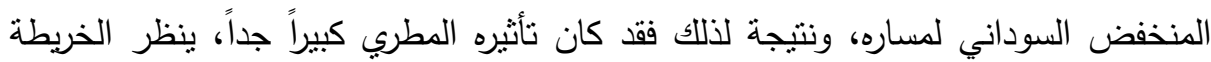

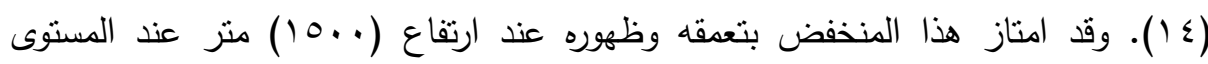

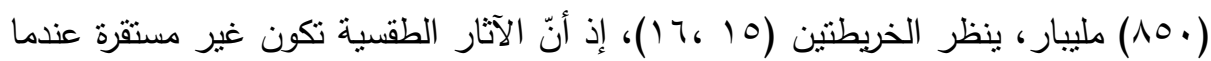

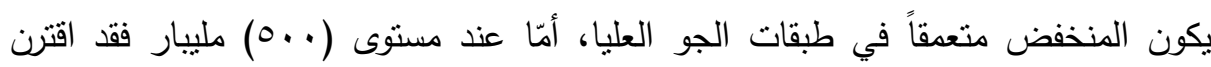

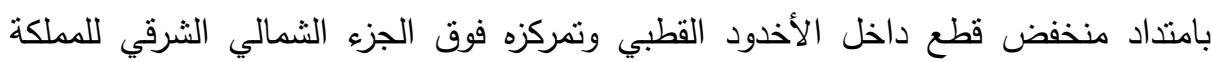

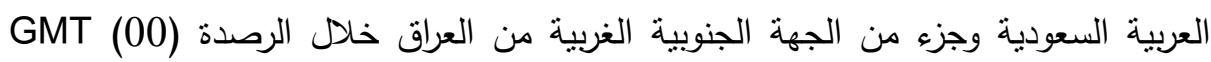
ينظر الخريطة (0)، ثم توغل باتجاه جنوبي غربي ليتمركز فوق شمال شرق البحر الاحمر لهن البنه

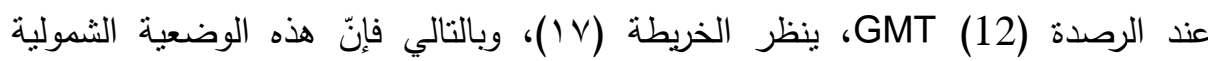
ساهدت في إحداث أعلى كمية نساقط مطري يومية في العراق في محطة العمارة، فعندما 
العــــــد الثــامن عثــر

يسيطر المنخفض السوداني فوق أجواء بعض مناطق العراق ويكون عميقاً ويقترن بمنخفض قطع في طبقات الجو العليا فإنّ أمطاره تكون أغزر وأكثف وهذا ماهو عليه الحال في محطة العمارة، وعلى هذا الأساس ايضاً فإنّ المنخفض السوداني هو المسؤول عن أعلى مطرة قياسية تساقطت في العراق خلال مدة البحث. 


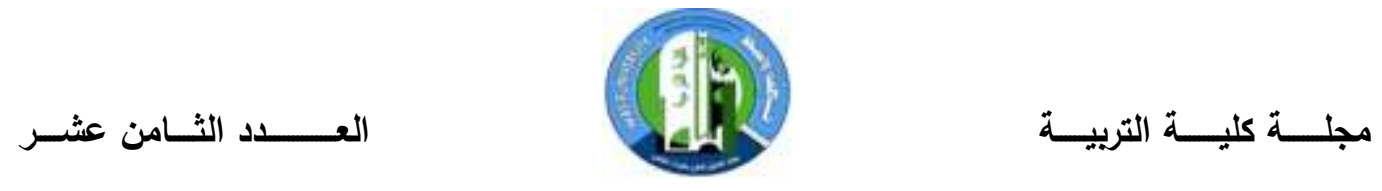

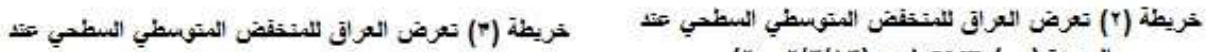

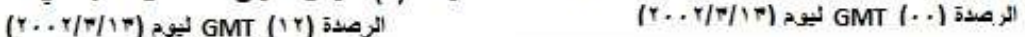

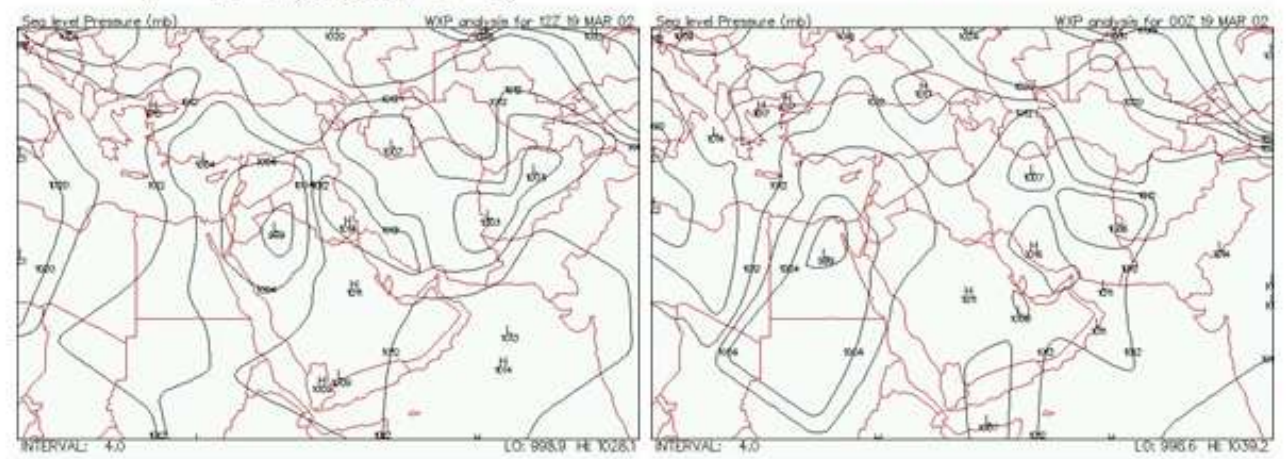

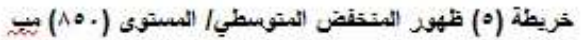

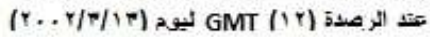

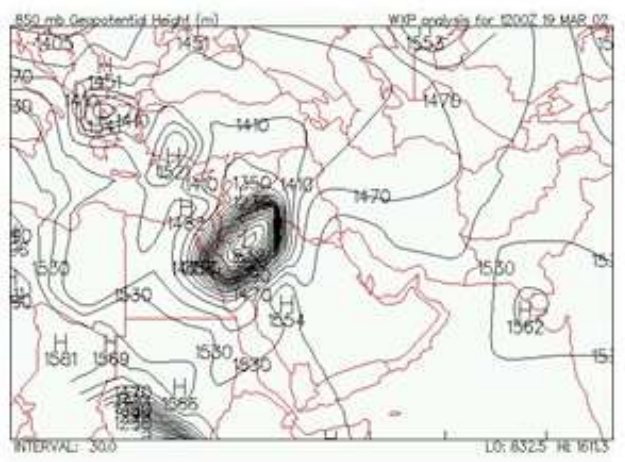

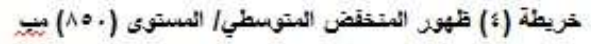

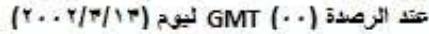

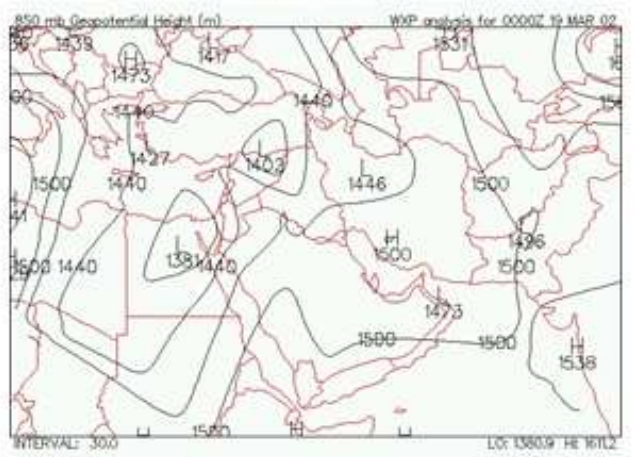

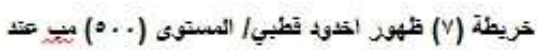

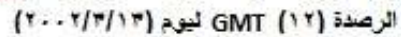

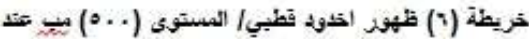

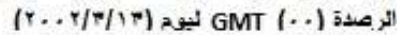
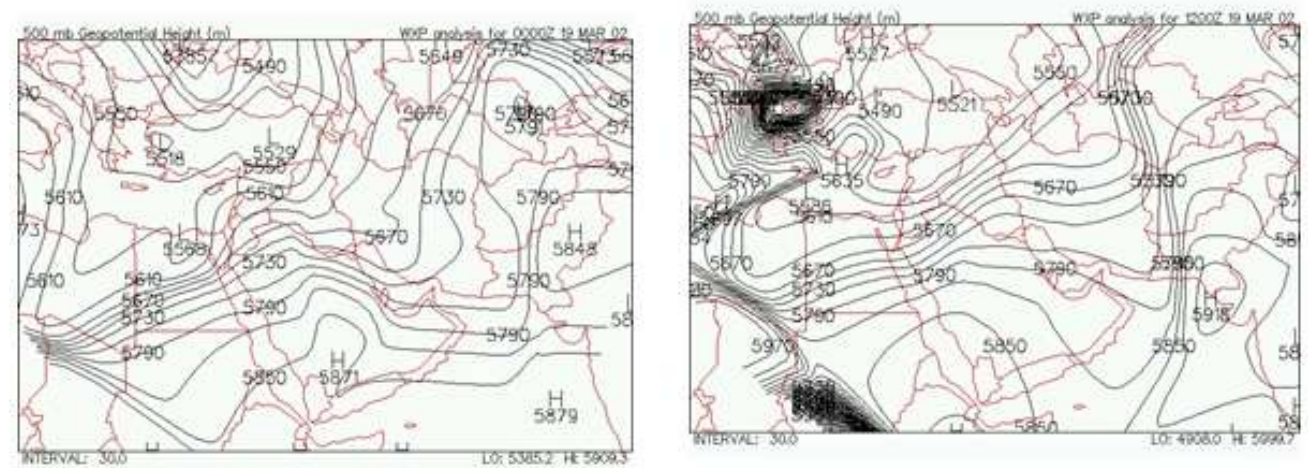


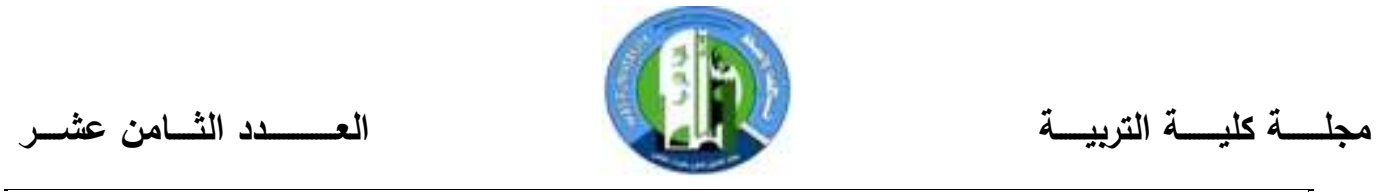

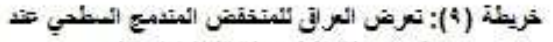

أرعدة (1\%

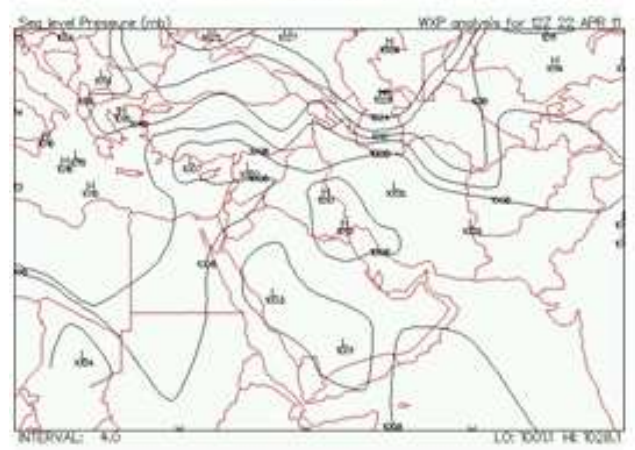

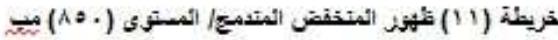

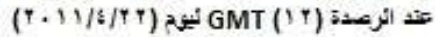

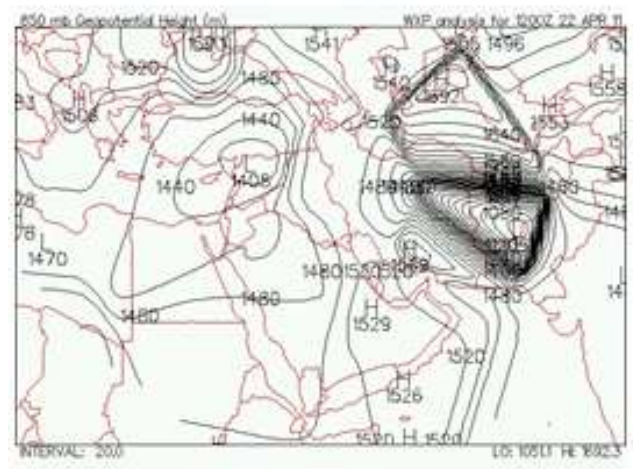

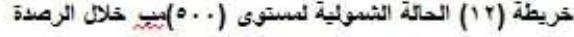

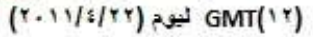

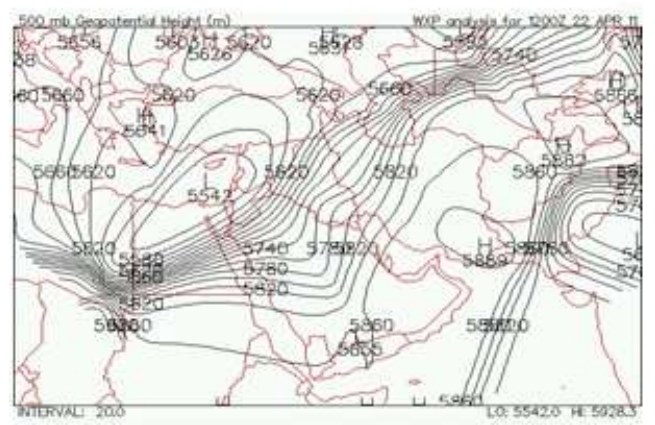

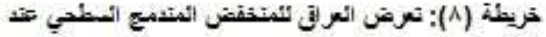

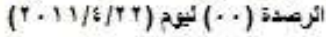

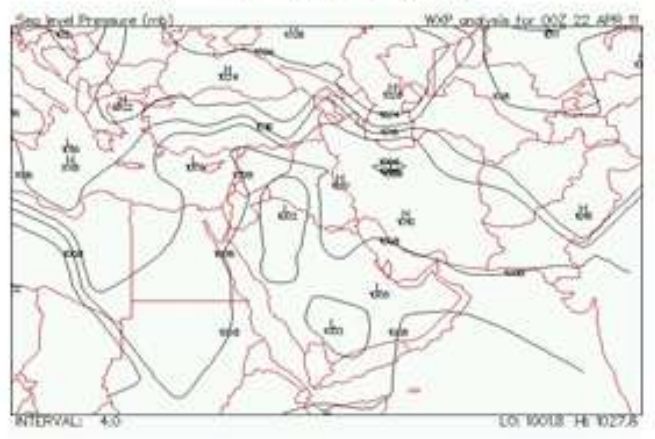

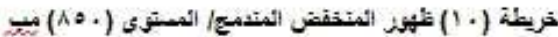

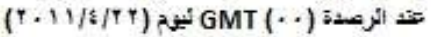

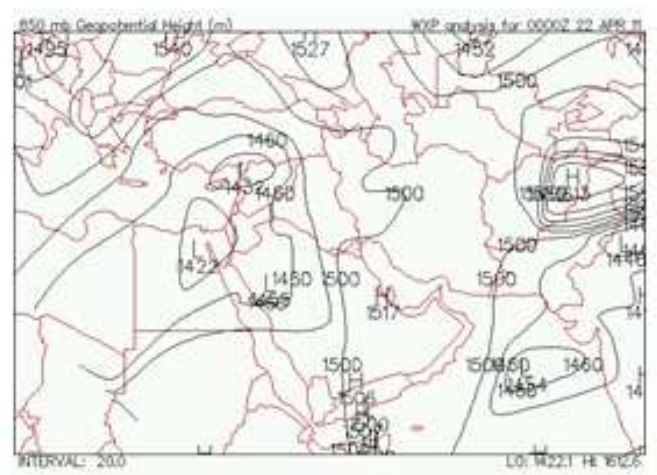

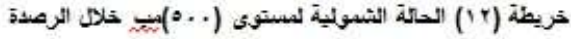

$$
\begin{aligned}
& \text { GMT(*) }
\end{aligned}
$$

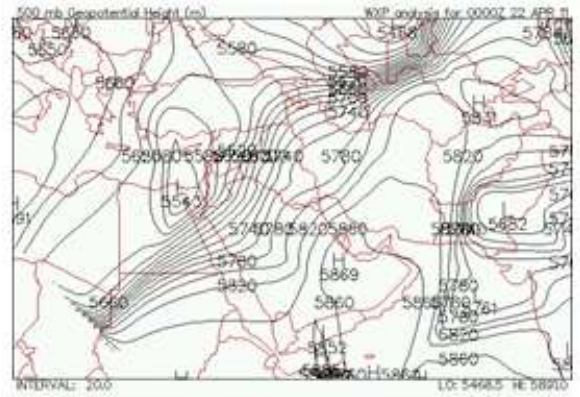




\section{العــــــد الثـــامن عشـــر

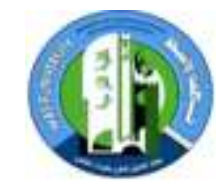

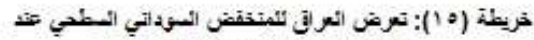

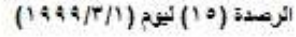

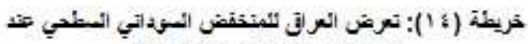 \\ (1948/T/1)}

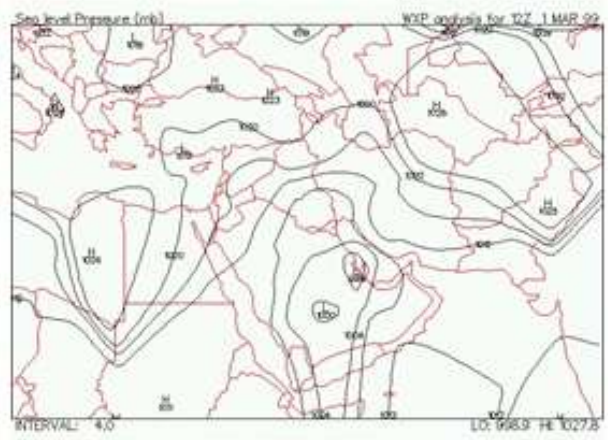

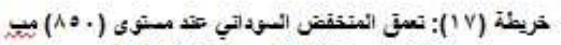

خلا الترعدة (1T)

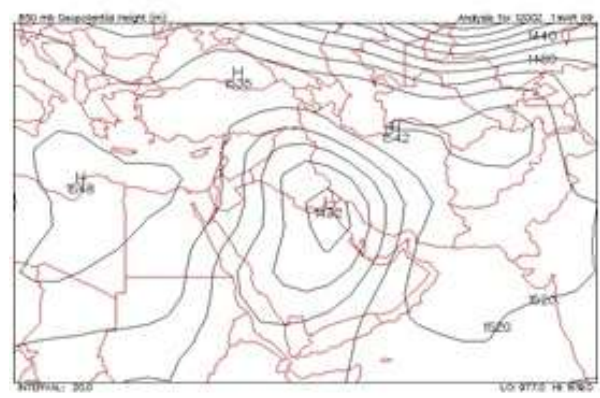

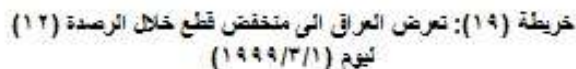

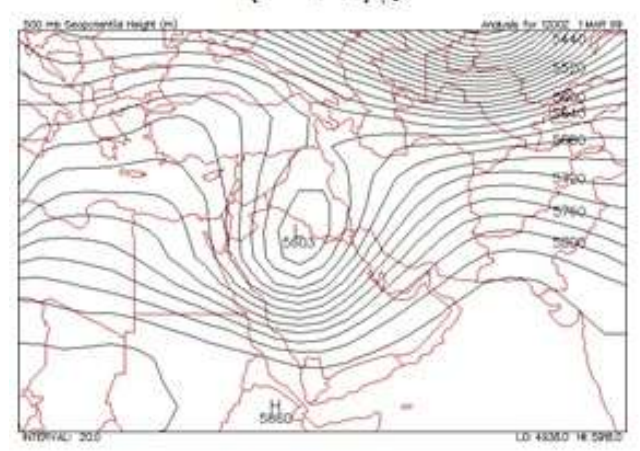

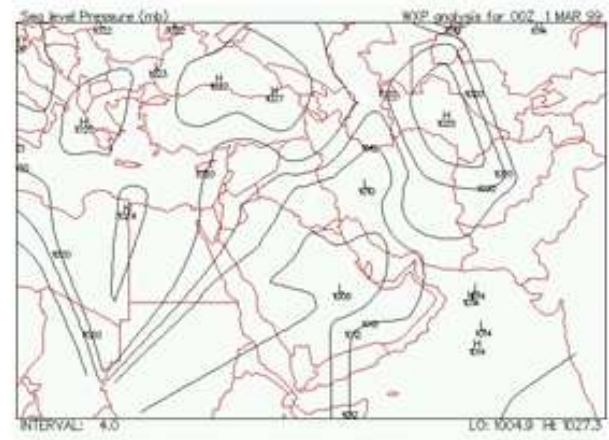

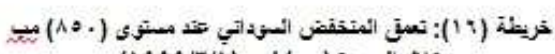

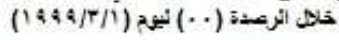

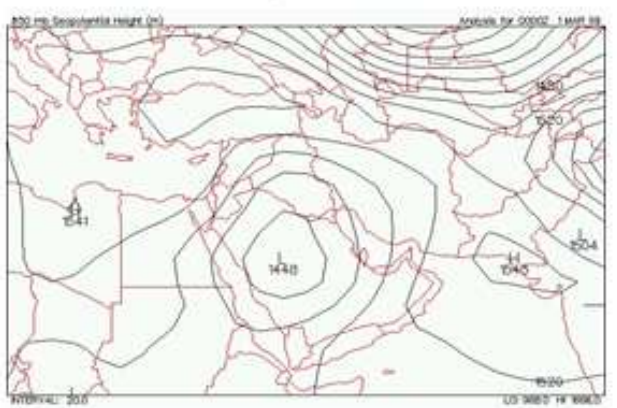

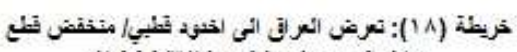

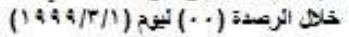

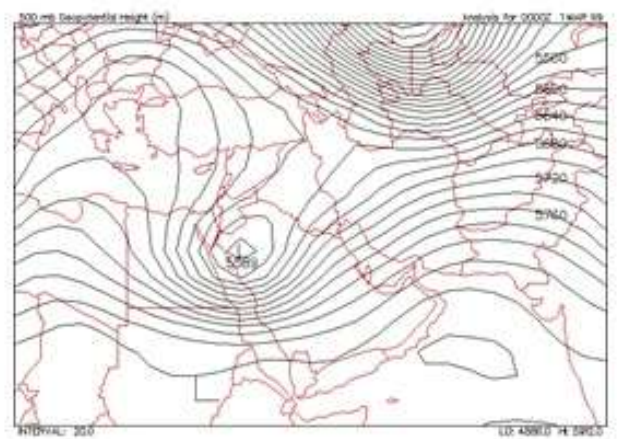




\section{الاستنتاجات}

خلصت الدراسة بمجموعة من النتائج أبرزها:

1- إنّ أعلى كمية نساقط مطري يومية مسجلة في العراق كانت في محطة العمارة في يوم |

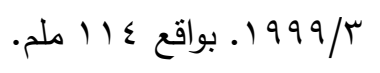

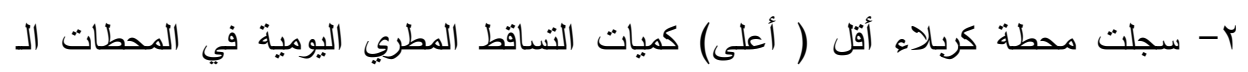

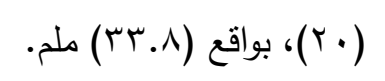

r- سجلت أعلى كميات مطرية يومية في خمسة أثنهر فقط من أثنهر موسم التساقط المطري

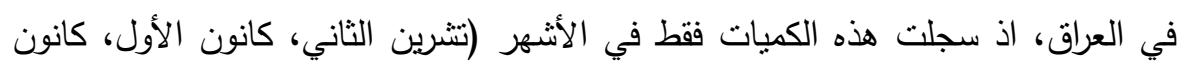

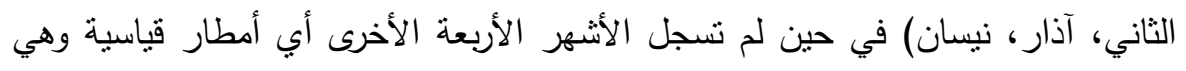

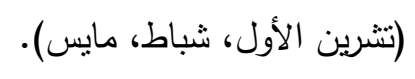

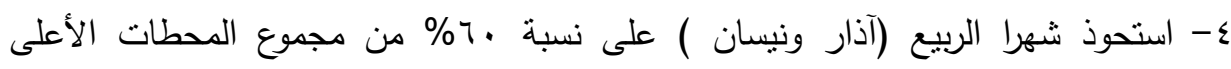

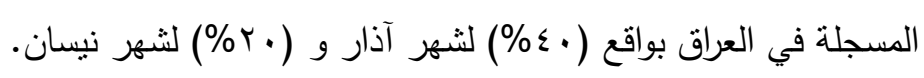

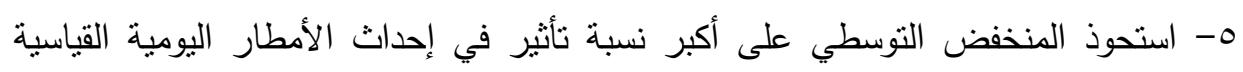

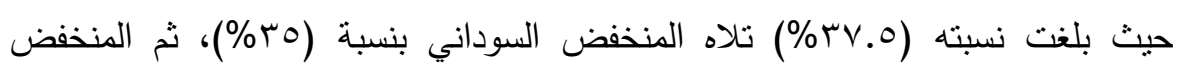

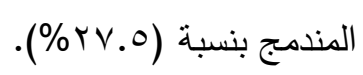

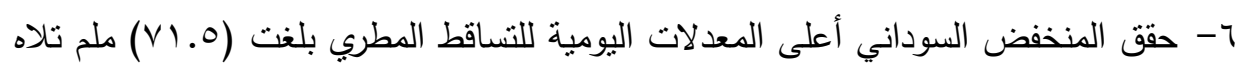

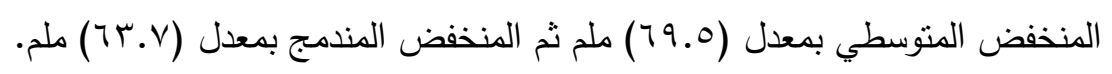
V- سجلت الاخاديد القطبية ومنخفضات القطع أكثر الأنماط الضغطية عند مستوى (. (.0) مليبار اقتراناً مع المنخفضات الجوية المنسبية في الأمطار اليومية القياسية في العراق. 


\section{المصادر}

ا ـ الدزيي، سالار علي خضر، مناخ العراق القديم والمعاصر، طا، دار الثؤون الثقافية العامة،

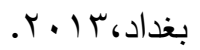

Y . عبد الباقي، فاتن خالد، ظواهر طبقات الجو العليا وأثرها في تشكيل وصباغة مناخ العراق،

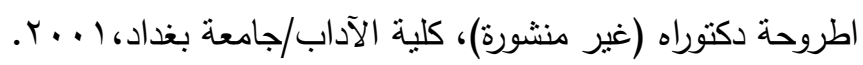

3. Barry, Roger.G and Chorley, Richard.D, Atmosphere, Weather And Climate, ${ }^{8}$ Edition, Rout ledge, London,2003.

4. Delrieu, G., Ducrocq The catastrophic flash-flood event of 89September 2002 in the Gard region, France: A first case study for the Cevennes-Vivarais Mediterranean Hydrometeorological Observatory. Journal of Hydrometeorology, 6(1): 34-52.

5. Oliver, John, Encyclopedia of World Climatology, Spring, Netheland, 2005.

6. Ramzah, Dambul, The Relationships between Large-scaleAtmospheric Circulation and SurfaceClimate: a Case Study for Borneo, A thesis ph, University of East Anglia, Norwich, England, 2005.

7. http://meteoseism.gov.iq.

8. http://www.vortex,Plymouth.edu الخرائط (r- 9 ( )مصدر

9. الهيأة العامة للأنواء الجوية والرصد الزلزالي العراقية، قسم المناخ (بيانات غير منشورة) 